Promoting Dignity and Preventing Shame and Humiliation by Improving the Quality and Education of Attorneys in Sexually Violent Predator (SVP) Civil Commitment Cases

Heather Ellis Cucolo

New YorkLaw School, heather.cucolo@nyls.edu

Michael L. Perlin

New York Law School, michael.perlin@nyls.edu

Follow this and additional works at: https://digitalcommons.nyls.edu/fac_articles_chapters

Part of the Legal Profession Commons, and the Supreme Court of the United States Commons

Recommended Citation

University of Florida Journal of Law and Public Policy, Vol. 28, Issue 2 (August 2017), pp. 291-328

This Article is brought to you for free and open access by the Faculty Scholarship at DigitalCommons@NYLS. It has been accepted for inclusion in Articles \& Chapters by an authorized administrator of DigitalCommons@NYLS. 


\title{
PROMOTING DIGNITY AND PREVENTING SHAME AND \\ HUMILIATION BY IMPROVING THE QUALITY AND \\ EDUCATION OF ATTORNEYS IN SEXUALLY VIOLENT \\ PREDATOR (SVP) CIVIL COMMITMENT CASES
}

\author{
Heather Ellis Cucolo ${ }^{*}$ \& Michael L. Perlin ${ }^{* *}$
}

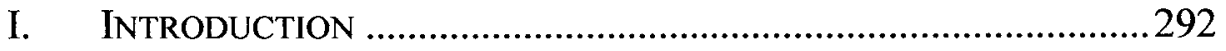

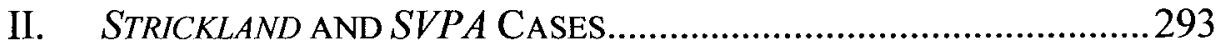

III. Shame, Humiliation ANd Lack of Dignity in the La W........296

IV. LACK OF COMPLIANCE WITH STRICKLAND

GUARANTEES AND THE RESULTING HARM ................................302

A. Psychometric Tests: The Scarlet Number ............................304

B. Evidence-Induced Humiliation ..............................................306

C. Shame in and out of Treatment ............................................ 308

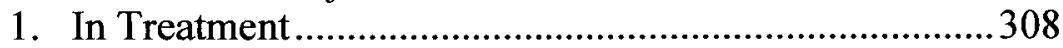

2. Out of Treatment ..............................................................311

D. Absence of Dignity in the Courtroom ................................. 313

E. How Attorneys Can Combat Client Feelings of Shame,

Humiliation and Lack of Dignity ....................................... 315

1. The Sanist Attorney ……………........................................315

2. Overcoming Shame........................................................... 317

3. Judgment is for the Court, not the Attorney.....................318

4. "Truth is for the Gods; From our Human Point of

View, It is an Ideal, Towards Which We can

Approximate, But Which We Cannot

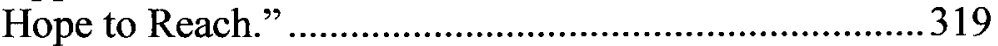

5. "Nothing in the World is More Dangerous than

Sincere Ignorance and Conscientious Stupidity."..........319

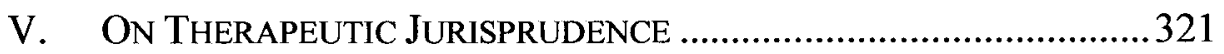

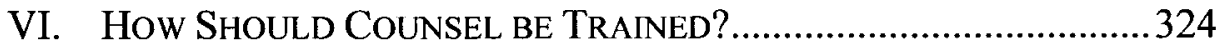

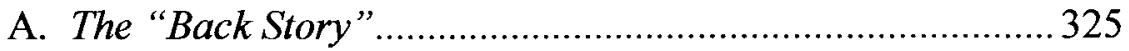

* Adjunct Professor, New York Law School; Co-founder, Mental Disability Law \& Policy Associates, L.L.C.

** Professor Emeritus of Law, New York Law School; Founding Director, International Mental Disability Law Reform Project; Founding Director, Online Mental Disability Law Program; Co-Founder, Mental Disability Law and Policy Associates. A.B., Rutgers University; J.D. Columbia University School of Law. 


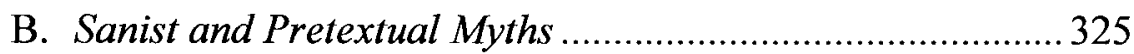

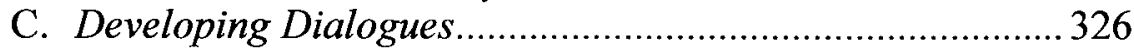

D. A Second Witness? .......................................................... 326

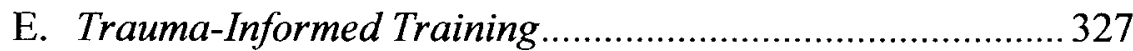

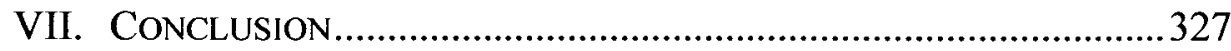

\section{INTRODUCTION}

In Strickland v. Washington, ${ }^{1}$ the Supreme Court defined the Sixth Amendment constitutional right to counsel to include the right to the effective assistance of counsel. ${ }^{2}$ In its decision, the Court acknowledged that the role of counsel is critical to the ability of the adversarial system to best ensure that just results are produced. ${ }^{3}$ The Court did not elaborately define this constitutional requirement; subsequently, lower courts have set the bar shockingly low. ${ }^{4}$ This Article examines the quality of attorneys who litigate Sexually Violent Predator Act (SVPA) cases, and concludes that a failure to apply a higher standard - beyond what was set out in Strickland - results in humiliation, shame, and lack of dignity for clients.

We define shame as the emotion we experience when we realize that we are not living up to our standards or ideals. "On a cognitive level, there is the painful awareness of being a failure, deficient, or inadequate. Shame can occur alone or with another who causes or heightens the experience. The shamed person feels exposed and wants to hide. ${ }^{5}$ Humiliation is the emotional experience of being lowered in status, usually by another person. There is the associated sense of powerlessness. Shame and humiliation are often felt in combination with one another, and thus we will refer to both and detail how these emotions are generated as a direct result of our treatment of individuals who have been labeled as sexual offenders.

The volatile "arranged marriage" of law and psychology in sex offender civil commitment cases requires attorneys to have a particular set of skills and knowledge in order to conduct a fair, judicious, and

1. Strickland v. Washington, 466 U.S. 668 (1984).

2. $I d$. at 685-86.

3. Id. at 685 .

4. For astounding examples in death penalty cases, see Michael L. PerLin, Mental Disability and the Death Penalty: The Shame of the States viii (2013).

5. Aaron Lazare \& Wilton S. Sogg, Shame, Humiliation and Stigma in the Attorney-Client Relationship, 47 PRAC. LAW. 11, 12 (2001).

6. See Michael L. Perlin, The Legal Status of the Psychologist in the Courtroom, $5 \mathrm{~J}$. PSYCHIATRY \& L. 41, 53 n.39 (1977). 
ethical trial, and to secure an accurate verdict. This is necessary to not only preserve the dignity of the legal system, but also to preserve the dignity of their clients facing what is most likely considered one of the most undignified adjudicative determinations: that of "sexually violent predator." Without specialized training and expert collaboration, attorneys cannot provide even remotely adequate or effective representation. ${ }^{7}$

In this Article, we explore how an understanding of the concepts of shame and humiliation is critical to an understanding of the legal issues we discuss here, and we will "tease out" the meanings of these concepts in the specific context of the way that representation is (or is not) provided in SVPA cases.

We will consider these issues in this manner: Part II will discuss the application of the Strickland standard in SVPA cases; Part III will consider the significance of shame and humiliation in the legal process and the need for the judicial process to enforce standards of dignity; Part IV will demonstrate the harms caused by the failure to comply with even the minimal Strickland standards; Part V will explain the bases of therapeutic jurisprudence, which is vital to any understanding of the underlying issues, and will offer suggestions to prevent and minimize client shame, humiliation, and lack of dignity; and Part VI will offer some modest conclusions.

\section{STRICKLAND AND SVPA CASES}

For the past thirty-three years, the standard set out by the Supreme Court in Strickland has governed the question of adequacy of counsel in criminal trials. Under Strickland, effectiveness of counsel is defined pallidly as requiring simply that counsel's efforts be "reasonable" under the circumstances. ${ }^{8}$ The benchmark for judging an ineffectiveness claim is simply "whether counsel's conduct so undermined the proper functioning of the adversarial process that the trial cannot be relied on as having produced a just result." ${ }^{\text {"9 }}$ Post-Strickland cases involving mental status issues outside the ken of most lawyers ${ }^{10}$ have re-enforced what

7. See generally Heather Ellis Cucolo \& Michael L. Perlin, "Far from the Turbulent Space": Considering the Adequacy of Counsel in the Representation of Individuals Accused of Being Sexually Violent Predators, 18 U. PA. J.L. \& Soc. CHANGE 125 (2015) [hereinafter Cucolo \& Perlin, "Far From the Turbulent Space"].

8. Strickland v. Washington, 466 U.S. 668 (1984). See also Gary Feldon \& Tara Beech, Unpacking the First Prong of the Strickland Standard: How to Identify Controlling Precedent and Determine Prevailing Professional Norms in Ineffective Assistance of Counsel Cases, 23 U. FLA. J.L. \& PUB. POL'Y 1, 2 (2012).

9. Strickland, 466 U.S. at 686.

10. See, e.g., Michael L. Perlin, The Jurisprudence of the InSAnity Defense 405 
Judge David Bazelon characterized some forty years ago as "walking violations of the Sixth Amendment," "11 and, in many instances, have produced "appalling results."12

Importantly, in Strickland, there was no hint at all as to what its impact might be on other cases that were not criminal prosecutions, but that potentially involved lengthy periods of institutionalization. ${ }^{13}$ Writing about Strickland some years ago, one of the co-authors (MLP) noted that the availability of organized, specialized, and aggressive counsel in civil commitment is largely illusory, and the level of representation remains almost uniformly substandard. ${ }^{14}$

Then, fifteen years ago, in In re Mental Health of K.G.F., ${ }^{15}$ the Montana Supreme Court acknowledged that the Strickland standard might not be a sufficient test of adequacy in cases involving involuntary civil commitment. ${ }^{16}$ The court eschewed the Strickland standard of effectiveness and instead found that the standard insufficiently protected the "liberty interests of individuals such as K.G.F., who may or may not have broken any law, but who, upon the expiration of a 90-day commitment, must indefinitely bear the badge of inferiority of a once 'involuntarily committed' person with a proven mental disorder."17 Importantly, one of the key reasons why Strickland was seen as lacking was the court's conclusion that "reasonable professional assistance"-the linchpin of the Strickland decision - "cannot be presumed in a proceeding that routinely accepts - and even requires - an unreasonably low standard of legal assistance and generally disdains zealous, adversarial confrontation." 18

The K.G.F. case profoundly recognizes the necessity to apply a more rigorous standard than the one accepted by the Supreme Court in Strickland-especially for proceedings that require specialized knowledge and expertise and have the potential to result in lifetime stigma and confinement. In the authors' opinions, there are no other

(1995); Michael L. Perlin, A Prescription for Dignity: Rethinking Criminal Justice and Mental Disability Law (2013) [hereinafter Perlin, A Prescription for Dignity].

11. David L. Bazelon, The Defective Assistance of Counsel, 42 U. CIN. L. REv. 1, 2 (1973).

12. Welsh S. White, Capital Punishment's Future, 91 MiCH. L. REv. 1429, 1436 (1993) (reviewing RAYMOND PATERNOSTER, CAPITAL PUNISHMENT IN AMERICA (1991)).

13. Cucolo \& Perlin, "Far From the Turbulent Space," supra note 7, at 128.

14. Michael L. Perlin, You Have Discussed Lepers and Crooks: Sanism in Clinical Teaching, 9 ClINICAL L. REV. 683, 690 (2003) (quoting, in part, Michael L. Perlin \& Deborah A. Dorfman, Is It More Than "Dodging Lions and Wastin' Time"? Adequacy of Counsel, Questions of Competence, and the Judicial Process in Individual Right to Refuse Treatment Cases, 2 PSyChOL. PUB. POL'y \& L. 114, 122 (1996)).

15. In re K.G.F., 29 P.3d 485, 492 (Mont. 2001).

16. Id. at 491 .

17. $I d$

18. Id. at 492 (citing Michael L. Perlin, Fatal Assumption: A Critical Evaluation of the Role of Counsel in Mental Disability Cases, 16 L. \& HuM. BeHAv. 39, 53-54 (1992)). 
proceedings more in need of a higher standard than SVPA proceedings, ones that are invariably and inevitably inundated with stigma, shame, and humiliation.

These Acts apply to "any person who has been convicted of or charged with a sexually violent offense and who suffers from a mental abnormality or personality disorder which makes the person likely to engage in the repeat acts of sexual violence." 19 Such individuals can be committed indefinitely; in a significant percentage of these cases, such commitments are, basically, life sentences. ${ }^{20}$

Such cases are, following the Supreme Court's decision in Kansas v. Hendricks, ${ }^{21}$ classified as "civil" rather than "criminal," because they involve "involuntary civil confinement of a limited subclass of dangerous persons." 22 Such persons are not only considered dangerous but are universally deemed to be the most despised and heinous population of individuals. ${ }^{23}$ Society's general revulsion toward this population is shared by judges, jurors and lawyers. ${ }^{24}$ Although the bar pays lip service to the bromide that counsel is available for all, no matter how unpopular the cause, the reality is that there are few volunteers for the job of representing these individuals, and that the public's enmity has a chilling effect on the vigorous of representation in this area.

Compounding the stigma associated with individuals who fall under the SVPA is the complex evidence often produced at SVPA proceedings. ${ }^{25}$ Expert witnesses commonly utilize and interpret several

19. KAN. StAT. ANN. \$ 59-29a02(a) (2016).

20. See, e.g., Jenny Roberts, The Mythical Divide between Collateral and Direct Consequences of Criminal Convictions: Involuntary Commitment of "Sexually Violent Predators," 93 MinN. L. REv. 670, 707 (2008).

21. Kansas v. Hendricks, 521 U.S. 346 (1997).

22. Id. at 356 .

23. See Heather Ellis Cucolo \& Michael L. Perlin, Preventing Sex-Offender Recidivism Through Therapeutic Jurisprudence Approaches and Specialized Community Integration, 22 TEMP. Pol. \& Civ. RTs. L. Rev. 1, 5 (2012) [hereinafter Cucolo \& Perlin, Preventing Sex-Offender Recidivism] ("Currently, no other population is more despised, more vilified, more subject to media misrepresentation, and more likely to be denied basic human rights."). Although it has been common wisdom for years that the phrase "the worst of the worst" was typically meant to refer to those subject to the death penalty, see, e.g., Kansas v. Marsh, 548 U.S. 163, 206 (2006) (Souter, J., dissenting) (" $[W]$ ithin the category of capital crimes, the death penalty must be reserved for 'the worst of the worst"'); in actuality, it is now generally reserved for this population, see Nora V. Demleitner, Misguided Prevention: The War on Terrorism as a War on Immigrant Offenders and Immigration Violators, 40 CRIM. L. BULL. 550, 573 (2004) (sex offenders are "styled as 'the worst of the worst' as a consequence ... of their sex offense").

24. Cucolo \& Perlin, Preventing Sex-Offender Recidivism, supra note 23, at 67; Kevin J. Breer, Beyond Hendricks: The United States Supreme Court Decision in Kansas v. Crane and Other Issues Concerning Kansas' Sexually Violent Predator Act, 71 J. KAN. BAR Ass'N 13 (2002) ("Sex offenders are the scourge of modern America, the "irredeemable monsters" who prey on the innocent.").

25. Many of these experts base their predictions heavily on "actuarial tests" such as: 
controversial psychometric tests, ${ }^{26}$ and in order to effectively combat such evidence lawyers must have familiarity with and a working knowledge of these instruments and with the literature about their validity and reliability. ${ }^{27}$ In many instances, counsel would need to consult with an independent expert to adequately defend his or her client's case. Without a guaranteed right to such expertise, it is even less likely that counsel will be able to ably launch a defense in such cases. ${ }^{28}$

\section{Shame, Humiliation and Lack Of Dignity in the LaW}

"Criminal justice policy regarding serious offenders is no longer focused on what was previously ' . . a progressive sense of justice, an evocation of what "decency" and "humanity" required, and a compassion for the needs and rights of the less fortunate." 22 Instead, sex offender treatment in the United States is influenced by legislation that increasingly characterizes sex offenders as "lifelong predators who will

- Vernon L. Quinsey et al., Violence Risk Appraisal Guide (VRAG), in Violent Offenders: Appraising and Managing Risk 283-86 (2d ed. 2006);

- Vernon L. Quinsey et al., Sex Offender Risk Appraisal Guide (SORAG), in Violent Offenders: Appraising and Managing Risk 24144 (1998);

- R. Karl Hanson, Dep'T of the Solicitor Gen. of Can., The Development of a Brief Actuarial Risk Scale for Sexual Offense Recidivism 14 (1997); and

- Douglas L. Epperson et al., Minnesota SEX OfFEnder Screening TOOL- Revised (MnSOST-R): Development, Validation, and Recommended Risk Level Cut Scores 36-38 tbl.2 (2003).

26. See, e.g., Terence W. Campbell, Assessing Sex Offenders: Problems and PITFALLS 76 (2004) (criticizing the STATIC-99 test), as discussed in Frederick E. Vars, Rethinking the Indefinite Detention of Sex Offenders, 44 CONN. L. REv. 161, 167 (2011). The Static-99 is a ten-item actuarial assessment instrument for use with adult male sexual offenders who are at least 18 year of age at time of release to the community. R. Karl Hanson \& David Thornton, STATIC-99 Tally Sheet, STATIC-99 ClEARINGHOUSE, http://www.static99.org/pdfdocs/ static-99-coding-rules_e71.pdf (last visited Jan. 1, 2014). It is the most widely used sex offender risk assessment instrument in the world, and is extensively used in the United States, Canada, the United Kingdom, Australia, and many European nations. Static-99 Documents, STATIC-99 ClEARINGHOUSE, http://www.static99.org (last visited Apr. 10, 2017).

27. Richard Hamill, Recidivism of Sex Offenders: What You Need to Know, 15 CRIM. JuST. 24, 30 (2001).

28. Although the Supreme Court has held in Ake v. Oklahoma, 470 U.S. 68, 86(1985), that a defendant has a right to an independent expert in a felony trial, there is scant analogous case or statutory law with regard to SVPA matters.

29. Astrid Birgden \& Heather Ellis Cucolo, The Treatment of Sex Offenders: Evidence, Ethics and Human Rights, 23 SEXUAL ABuSE: J. ReS. \& TREATMENT 295, 295 (2011) (citations omitted). 
seek out new victims as long as they live." 30

In a previous article, one of the co-authors (MLP) argued, "humiliation and shaming contravene basic fundamental human rights and raise important constitutional questions." ${ }^{" 31}$ These practices lead to recidivism, inhibit rehabilitation, discourage treatment, and injure victims. ${ }^{32}$ They also directly contravene the guiding principles of therapeutic jurisprudence (TJ) especially in the context of its relationship to the importance of dignity in the law. ${ }^{33}$ We believe that nowhere is this more so than in the context of SVPA cases.

Shame forces a downward redefinition of oneself;", "the thrust of [shame's] aggression is to dehumanize." 35 It is bordered by "embarrassment, humiliation, and mortification, in porous ways that are difficult to predict or contain,"36 and is "one of the most important, painful and intensive of all emotions." $" 37$ Shaming is public; its dehumanization and social demotion occurs when a shameful trait or act becomes "visible, and is exposed to others."

According to Professor Martha Nussbaum, when "shame is a large part of their problem ... expos [ing] that person to humiliation may often shatter the all-too-fragile defenses of the person's ego. The result might be utter collapse. ${ }^{39}$ By marginalizing the rights of those who are shamed and humiliated, such individuals are treated as less than human. ${ }^{40}$

30. Id. at 296 (citations omitted).

31. Michael L. Perlin \& Naomi M. Weinstein, "Friend to the Martyr, a Friend to the Woman of Shame": Thinking About the Law, Shame and Humiliation, 24 S. CAL. REV. L. \& SOC. JUST. 1, 5 (2014).

32. Id.

33. See, e.g., Michael L. Perlin, "There Are No Trials inside the Gates of Eden": Mental Health Courts, the Convention on the Rights of Persons with Disabilities, Dignity, and the Promise of Therapeutic Jurisprudence, in COERCIVE CARE: RIGHTS, LAW AND POLICY 193, 196 (Bernadette McSherry \& Ian Freckelton eds., 2013). In the context of sex offender law, see Cucolo \& Perlin, Preventing Sex-Offender Recidivism, supra note 23, at 34-35.

34. Toni M. Massaro, Shame, Culture, and American Criminal Law, 89 MicH. L. REv. 1880, 1901 (1991) [hereinafter Massaro, Shame, Culture, and American Criminal Law].

35. LeON WURMSER, ThE MASK OF Shame 81 (1981) (emphasis added).

36. Toni M. Massaro, The Meanings of Shame: Implications for Legal Reform, 3 PSYCHOL. PUB. PoL'Y \& L. 645, 703 (1997) [hereinafter Massaro, The Meanings of Shame].

37. Robert Svensson et al., Moral Emotions and Offending: Do Feelings of Anticipated Shame and Guilt Mediate the Effect of Socialization on Offending?, 10 EUR. J. CRIMINOLOGY 22, 23 (2013).

38. Massaro, Shame, Culture, and American Criminal Law, supra note 34, at 1901 (citing CARL D. SCHNeIder, Shame, EXPosure and Privacy 34-35 (1977)).

39. Martha C. Nussbaum, Hiding From Humanity: Disgust, Shame, and the Law 236 (2004).

40. Anita Bernstein, Treating Sexual Harassment with Respect, 111 HARV. L. REV. 445, 489-90 (1997). On how humiliation is contrary to both the aims of therapeutic jurisprudence, see infra Part VI, and restorative justice, see, e.g., Kathleen Daly, Restorative Justice and Sexual Assault: An Archival Study of Court and Conference Cases, 46 BRIT. J. CRIMINOLOGY 334, 335 36 (2006) (providing a brief description of restorative justice); PERLIN, A PRESCRIPTION FOR DignITY, supra note 10, at 79. Restorative justice is a means by which to restore victims, restore 
Shaming sanctions may be psychologically debilitating. Carole McKindley-Alvarez, the director of a mental health program for juveniles, has directly criticized the shaming approach stating that "[a]ll of our mental health programs end up having more and more people come in with trauma at the hands of humiliation ... the behavior [will] show up in different ways ... [and] unfortunately, the morgue may see that person." ${ }^{.41}$ Importantly, in the context of this article, shaming "exploits one's fear of shunning by others, or of banishment from the community." 42

In addition, proponents of shaming sanctions fail to recognize that shaming sanctions convey the message that offenders are less than human and that offenders deserve our individual and collective contempt. ${ }^{43}$ "Sending this kind of message, even about criminal offenders, is, and should be, jarring in a political order that makes equality a cultural baseline. ${ }^{.44}$ It is hard to imagine how shaming penalties that are crude and degrading will foster respect for the law. ${ }^{45}$ It is more likely that they are frequently counter-productive. ${ }^{46}$

"Three common maladaptive responses to shame are depression,

offenders, and restore communities "in a way that all stakeholders can agree is just." John Braithwaite, A Future Where Punishment Is Marginalized: Realistic or Utopian?, 46 UCLA L. REV. 1727, 1743 (1999); see, e.g., Michael G. Petrunik, Managing Unacceptable Risk: Sex Offenders, Community Response, and Social Policy in the United States and Canada, 46 INT'L J. OFFENDER THERAPY \& COMP. CRIMINOLOGY 483, 506 (2002) (comparing risk management model for control of sex offenders with earlier models, and with a restorative justice model), there isto the best of our knowledge - only one mention in the legal literature (a student note) that raises the potential connection between restorative justice and shaming in a sex offender context. See Meaghan Kelly, Lock Them Up and Throw Away the Key: The Preventive Detention of Sex Offenders in the United States and Germany, 39 GEO. J. INT'L L. 551, 572 (2008). There is nothing in the literature that raises its connection with humiliation.

41. Luke Coyne, Can Shame Be Therapeutic?, 7 ARIz. Summit L. Rev. 539, 557 (2012).

42. Massaro, Shame, Culture, and American Criminal Law, supra note 34, at 1903. Beyond the scope of this Article is the further discussion of banishment through residency restrictions in the community. See Cucolo \& Perlin, Preventing Sex-Offender Recidivism, supra note 23, at 40.

43. Massaro, The Meanings of Shame, supra note 36, at 699.

44. Id. at 700 .

45. Paul Ziel, Eighteenth Century Public Humiliation Penalties in Twenty-First Century America: The "Shameful" Return of "Scarlet Letter" Punishments in U.S. v. Gementera, 19 BYU J. PUB. L. 499, 509-10 (2005).

46. On how some police actions shame and humiliate persons with mental disabilities in general, see Michael L. Perlin \& Alison J. Lynch, "To Wander Off in Shame": Deconstructing the Shaming and Shameful Arrest Policies of Urban Police Departments in Their Treatment of Persons with Mental Disabilities, in POWER, Humiliation AND Violence (forthcoming Daniel Rothbart ed., 2017) (manuscript, at 14) (on file with authors), available at https://papers.ssrn.com/sol3/papers.cfm?abstract_id=2839820. On how our juvenile justice system shames and humiliates juveniles facing civil commitment and those facing criminal confinement, see Michael L. Perlin \& Alison J. Lynch, "She's Nobody's Child/The Law Can't Touch Her at All": Seeking to Bring Dignity to Legal Proceedings Involving Juveniles 13 (unpublished manuscript) (on file with author), available at https://papers.ssrn.com/sol3/papers. cfm?abstract_id=2912499 [hereinafter Perlin \& Lynch, Nobody's Child]. 
hiding/avoidance, and anger. ${ }^{\$ 47}$ Hiding/avoidance can often lead to a denial of the problem. ${ }^{48}$ Anger may lead to acts of revenge. ${ }^{49}$ These behavioral responses to shame are likely to undermine the goals of shaming. ${ }^{50}$ It is no wonder, since "the natural response to shame is to cover the source of the shame[.]" ${ }^{51}$ And, the all-too-frequent "response to sexual shame seems to be: more shame." 52

The determinants of shame have been identified as:

- The shame-inducing event;

- The vulnerability of the subject; and

- The social context, which includes the roles of people involved. ${ }^{53}$

We argue here that the shame-inducing event (in this case, the SVPA hearing) and the individual's vulnerability ultimately interact with a social context when the client seeks professional help. Thus, the entire structure of the SVPA system is one that is based on shame and humiliation.

Society constructs this population as "monsters" so that we can more easily dehumanize them. ${ }^{54}$ Those subject to SVPA proceedings are marginalized even further and it is virtually impossible for any fact-finder to "connect with" or empathize with the victims on any level. ${ }^{55}$ Nearly twenty years ago, a student comment noted that "it is a reasonable emotional response to desire revenge upon the sex offender, not to care about his civil rights, and to see him as less than human." ${ }^{56}$ Recently, one of the co-authors (MLP) has argued that the use of humiliation techniques, "whether done in overt or passive ways, [also] violates rights to due process, privacy, and freedom from cruel and unusual punishment." 57

The public justifies the devaluation of the rights of convicted sex

47. Lazare \& Sogg, supra note 5, at 15.

48. Id.

49. Id.

50. Toni M. Massaro, Show (Some) Emotions, in THE PASsions of LAW 80, 99 (Susan Bandes ed., 1999).

51. George P. Fletcher, Thinking about Eden: A Tribute to Herbert Morris, 22 QUINNIPIAC L. REV. 1, 16 (2003).

52. Michael, Warner, The Trouble with Normal: Sex, Politics, and the Ethics of QUEER LIFE 3 (1999).

53. Lazare \& Sogg, supra note 5, at 12.

54. Edward J. Imwinkelried, Undertaking the Task of Reforming the American Character Evidence Prohibition: The Importance of Getting the Experiment off on the Right Foot, 22 FORDHAM URB. L.J. 285, 296 (1995).

55. Fredrick E. Vars, Fear of an Undeterrable Other, 75 LA. L. REV. 1, 16 (2014).

56. Amy M. Lageman, Dangerous Offender Legislation: A Short Term Solution to a Long Term Problem, 16 DICK. J. INT'L L. 203, 224 (1997).

57. Perlin \& Weinstein, supra note 31 , at 10. 
offenders because of the incessant dehumanizing portrayal of them as "lions in the tall grass waiting to attack," "monsters," "beast[s]," and even "the human equivalent of toxic waste." 58

It is no surprise that the vast majority of sex offenders self-report being humiliated on a daily basis. ${ }^{59}$ Humiliation has been broadly defined as "the rejection of human beings as human, that is, treating people as if they were not human beings but merely things, tools, animals, subhumans, or inferior humans." ${ }^{\circ 0}$ Humiliation can also reflect "a loss of control over one's identity," or "being denied a certain status in communion with others." $" 61$

We have argued in the past that this dehumanizing treatment ${ }^{62}$ may have the effect of actually increasing sex offender recidivism rates. ${ }^{63}$ Philosopher Jeremy Waldron has noted that the predictable response to humiliation is for its target to "lash out at the humiliator" via a combination of anger and fear. ${ }^{64}$ Aggression seems to be predictably, automatically, and at times, uncontrollably activated in response to humiliation. ${ }^{65}$

While humiliation and shame share many characteristics, humiliation involves more emphasis on an interaction in which one is debased or forced into a degraded position by someone who is, at that moment, more powerful. ${ }^{66}$ Humiliation is also interpersonal, rather than wholly internal

58. Amy Grover, Delinquency and Punishment: The Impact of State v. Williams on Juvenile Sex Offender Registration in Ohio, 81 CIN. L. REv. 291, 302-03 (2013) (citations omitted).

59. Richard G. Zevitz \& Mary Ann Farkas, U.S. DEP'T OF Just., SEX OfFENDER COMMUNITY NOTIFICATION: ASSESSING THE IMPACT IN WISCONSIN 9 (2002), www.ncjrs.gov/ pdffiles 1/nij/179992.pdf (finding that $75 \%$ of interviewed sex offenders told of being humiliated in their daily lives due to expanded notification actions).

60. Bernstein, supra note 40, at 489 (quoting Avishai Margalit, THE DECENT SOCIETY 121 (1996)).

61. Claire Wright, Censoring the Censors in the WTO: Reconciling the Communitarian and Human Rights Theories of International Law, 3 J. INT'L MEDIA \& ENT. L. 17, 102 n.534 (2010).

62. This dehumanization has occurred at least since the days of J. Edgar Hoover who described the "sex fiend" as the "most loathsome of all the vast army of crime." Vars, supra note 55 (citing Jack Frosch \& Walter Bromberg, The Sex Offender-A Psychiatric Study, 9 AM. J. ORTHOPSYCHIATRY 761 (1939)).

63. Heather Ellis Cucolo \& Michael L. Perlin, "They're Planting Stories in the Press": The Impact of Media Distortions on Sex Offender Law and Policy, 3 U. DENV. CriM. L. REv. 185, 210 (2013) (citing J.J. Prescott \& J.E. Rockoff, Do Sex Offender Registration and Notification Laws Affect Criminal Behavior?, 54 J.L. \& ECON. 161 (2011)).

64. Jeremy Waldron, On Humiliation, 93 MiCH. L. REV. 1787, 1801 (1995) (reviewing William Ian MIler, Humliation, and Other Essays on Honor, SOCial Discomfort, aND VIOLENCE (1993)).

65. Diane Trumbull, Humiliation: The Trauma of Disrespect, 36 J. AM. ACAD. Psychoanalysis 643, 650 (2008).

66. Linda M. Hartling \& Tracy Luchetta, Humiliation: Assessing the Impact of Derision, Degradation, and Debasement, 19 J. PrIMARY Prevention 259, 262 (1999) (citing Susan B. Miller, Humiliation and Shame, 52 BuLl. MENNINGER ClinIC 40 (1988)). 
to a person (as shame may be), and often triadic, "requiring one who humiliates, one who is humiliated, and one witness (or more) whose good opinion is important to the one humiliated." ${ }^{67}$ Studies show the devastating consequences of systematic humiliation ${ }^{68}$ and demonstrate that humiliation can cause depression, paranoia, violence, generalized and social anxiety, and suicide. ${ }^{69}$

In recent years, scholars and activists from multiple disciplines have begun to devote themselves to the study of humiliation and how it robs the legal system and society of dignity. ${ }^{70}$ The Human Dignity and Humiliation Studies Network explicitly underscores this in its mandate: "We wish to stimulate systemic change, globally and locally, to open space for dignity and mutual respect and esteem to take root and grow, thus ending humiliating practices and breaking cycles of humiliation throughout the world." 71

It is important to note that there is almost no empirical evidence that shows that shaming sanctions improve society and no empirical evidence supporting the position that shaming sanctions are beneficial to the victims of the offense. ${ }^{72}$ There have been no comprehensive studies as to whether they are even effective, nor is there any empirical work through which the practical impact of such sanctions can be tested. ${ }^{73}$

It is necessary to contextualize all of this with the notion of dignity. ${ }^{74}$ Professor Carol Sanger has suggested that dignity means that people "' possess an intrinsic worth that should be recognized and respected,' and that they should not be subjected to treatment by the state that is inconsistent with their intrinsic worth." ${ }^{.75}$ A notion of individual dignity-generally articulated through concepts of autonomy, respect, equality, and freedom from undue government interference-was at the heart of a jurisprudential and moral outlook that resulted in the reform,

67. Catherine L. Fiske, Humiliation at Work, 8 WM. \& MARY J. WOMEN \& L. 73, 77 (2001) (citing Francis J. BROUCEK, SHAME AND THE SELF 75 (1991)).

68. Fiske, supra note 67 , at 76 . On systemic humiliation in general, see Arland D. Jacobson, The Role of Humiliation in International Conflict, 1 N. PLAINS ETHICS J. 65, 78-79 (2013).

69. Fiske, supra note 67 , at 78 (citing Donald C. Klein, The Humiliation Dynamic: An Overview, 12 J. Primary Prevention 93, 107-12 (1991)).

70. Perlin \& Weinstein, supra note 31 , at 5.

71. Id. at 5-6; see generally Welcome to Human Dignity and Humiliation Studies, HuM. DiGNITY \& HUMLIATION STUD., http://www.humiliationstudies.org/ (last visited Jan. 29, 2017).

72. Coyne, supra note 41 , at 555-56, 561 .

73. Perlin \& Weinstein, supra note 31, at 24 (citing Brian Netter, Avoiding the Shameful Backlash: Social Repercussions for the Increased Use of Alternative Sanctions, 96 J. CRIM. L. \& CRIMINOLOGY 187, $215(2005)$ ).

74. On the relationship between dignity and "human worth," see Amanda Ploch, Why Dignity Matters: Dignity and the Right (or Not) to Rehabilitation from International and National Perspectives, 44 N.Y.U. J. INT'L L. \& POL. 887, 895-97 (2012).

75. Carol Sanger, Decisional Dignity: Teenage Abortion, Bypass Hearings, and the Misuse of Law, 18 COLUM. J. GENDER \& L. 409, 415 (2009). 
not only of criminal procedure, but of the various institutions more or less directly linked with the criminal justice system, including juvenile courts, prisons, and mental institutions. ${ }^{76}$

Fair process norms such as the right to counsel "operate as substantive and procedural restraints on state power to ensure that the individual suspect is treated with dignity and respect." only by American constitutional norms; ${ }^{78}$ international human rights law also requires it. ${ }^{79}$ These principles should apply equally in the context of the treatment of sex offenders who are-we can never forgetinstitutionalized as civil patients. ${ }^{80}$

\section{LACK OF COMPLIANCE WITH STRICKLAND GUARANTEES AND THE RESUlting HARM}

An individual facing civil commitment as a sex offender may be assigned counsel but is not necessarily afforded the absolute right to have an appointed attorney. ${ }^{81}$ Jurisdictions vary on the availability and constitutionality of the Sixth Amendment right to counsel. ${ }^{82}$ By way of example, if a person is indigent, Kansas has required the State to provide, at public expense, the assistance of counsel and an examination by mental health care professionals. ${ }^{83}$ The Kansas Court of Appeals has mandated that if appointed counsel is not engaged, not responsive or otherwise not active, the court is obligated to investigate or to appoint new counsel declaring that there is a clear statutory requirement that counsel be provided "at all stages of the proceedings." 84 Yet in other states, the right

76. Eric J. Miller, Embracing Addiction: Drug Courts and the False Promise of Judicial Interventionism, 65 OHJO ST. L.J. 1479, 1569 n.463 (2004).

77. Peter Arenella, Rethinking the Functions of Criminal Procedure: The Warren and Burger Courts' Competing Ideologies, 72 GEO. L.J. 185, 200 (1983).

78. See Perlin \& Weinstein, supra note 31, at 18-19 (discussing, inter alia, Lawrence v. Texas, 539 U.S. 558, 578-79 (2003) (declaring unconstitutional Texas sodomy law)); Safford Unified School District No. 1 v. Redding, 557 U.S. 364, 366 (2009) (strip search of 13 year old girl by school principal violated her expectations of privacy); United States v. Windsor, $133 \mathrm{~S}$. Ct. 2675 (2013) (striking down portions of Defense of Marriage Act)).

79. See, e.g., Michael L. Perlin, "Striking for the Guardians and Protectors of the Mind": The Convention on the Rights of Persons with Disabilities and the Future of Guardianship Law, 117 PENN ST. L. REv. 1159, 1174-76 (2013) (discussing dignity requirements in U.N. Convention on the Rights of Persons with Disabilities).

80. See Michael L. Perlin \& Heather Ellis Cucolo, Shaming the Constitution: The Detrimental Results of SEXUAL Violent PREDATOR Legislation (2017).

81. Ramsey v. Runion, No. 2:1 lcv396, 2012 WL 3883378, at *5 (E.D. Va. Sept. 5, 2012); Cucolo \& Perlin, "Far from the Turbulent Space," supra note 7, at 134.

82. See Commitment of Dodge, 2013 IL App (1st) 113603, I 20 (although the Sexually Violent Persons Commitment Act (Act) proceedings are civil in nature, the Act provides a defendant with the right to effective assistance of counsel as provided in Strickland).

83. KAN. STAT. ANN. \& 59-29a06 (2017).

84. In re Miles, 213 P.3d 1077, 1080 (Kan. Ct. App. 2009). Citing to petitioners' pro se 
to counsel at each stage in the commitment process is not automatically granted and has been denied during pre-commitment evaluations ${ }^{85}$ as well as during the psychological evaluation for the annual review hearing. ${ }^{86}$

The quality of counsel and the threshold of constitutional rights have been debated in cases where defendants have sought to withdraw a plea bargain because they were not informed of the potential consequences of a sex offender conviction. The Supreme Court has yet to address this issue, and there is lack of uniformity in the state courts. New Jersey appears to be one of the only states that require counsel to inform the defendant that pleading guilty might qualify them for sexual offender civil commitment. ${ }^{87}$ Other state courts have mandated a duty to inform when the plea would result in sexual offender registration. ${ }^{88}$ Most state courts found no duty to inform, because civil commitment is not a direct result of the plea, but merely a collateral consequence. ${ }^{89} \mathrm{~A}$ South Carolina court ruled that although the criminal conviction is the triggering event for the SVPA the attorney had no duty to inform the offender about the SVPA before he pleaded guilty. ${ }^{90}$ The Kansas Court of Appeals reasoned that even if the defendant was informed of the SVPA, the chance of losing at trial and facing a longer prison sentence, would deter a guilty plea retraction. The question remains whether the defendant's decision to plead guilty took into account the fact that a potential life sentence

response, the court underscored:

The problem Petitioners are experiencing is with the attorneys appointed by the Court of Wyandotte County. These attorney's [sic] of record rarely, if ever, consult with their clients during the annual review period and almost never send any documentation as to any judgment or action taken in their case. Hence, the patient has no alternative to but to file his own petition without the assistance of counsel.

Id. at $1082-83$.

85. See, e.g., Greenfield v. N.J. Dep't of Corr., 888 A.2d 507, 511 (N.J. Super. Ct. App. Div. 2006) (sex offender had no due process right to review materials or meet with a committee addressing his possible referral to the state's attorney general for commitment as a sexually violent predator).

86. In re Petersen, 980 P.2d 1204, 1215 (Wash. 1999).

87. State v. Bellamy, 835 A.2d 1231, 1234 (N.J. 2003) (holding that prior to accepting a guilty plea to a predicate offense, trial courts must inform defendants of possible consequences under the Act).

88. Taylor v. State, 698 S.E.2d 384, 385 (Ga. Ct. App. 2010) (holding that counsel is constitutionally deficient if they did not advise their client that pleading guilty will subject the client to the sex offender registration requirements).

89. In re Campbell, 986 P.2d 771, 780-81 (Wash. Ct. App. 1999) (en banc), cert. denied, 531 U.S. 1125 (2001) (holding that a civil commitment, like sex offender registration, is a collateral consequence of pleading guilty and does not violate the plea agreement).

90. Page v. State, 615 S.E.2d 740, 742 (S.C. 2005); see Roberts, supra note 20, at 693-700 (providing an insightful look into collateral consequences discussed in Page v. State). 
attached to civil commitment.

We cannot merely consider the constitutional right to counsel but must discuss that right in combination with the quality of counsel and the ability of counsel to minimize clients' shame, humiliation and the resulting lack of dignity. To be successful in this endeavor, attorneys must understand the contributing factors that occur during SVPA court proceedings. Some of these factors include: the effects of psychometric tests; the use of hearsay evidence; the lack of confidentiality in treatment and use of treatment-induced statements in court; and the resulting condemnation of judges.

\section{A. Psychometric Tests: The Scarlet Number}

Expert predictions of future violence, which is "central to the ultimate question [of] ... whether petitioners suffer from a mental abnormality or personality disorder,"91 are believed to be necessary in the civil commitment of sexual offenders. ${ }^{92}$ The concept that humans can accurately predict the criminal or aberrant behavior of other humans in the long-term future has created the need for the development of actuarial instruments that allegedly remove the "human" element of error when predicting future risk.93

In greatly simplified terms, there are two broad approaches to conducting risk assessments to predict future dangerous sexual behavior: clinical judgment and actuarial assessment. ${ }^{94}$ The clinical approach requires evaluators to consider a wide range of risk factors and then form an overall opinion concerning future dangerousness. ${ }^{95}$ The actuarial approach evaluates a limited set of predictors and then combines these variables using a predetermined, numerical weighting system to determine future risk of re-offense, ${ }^{96}$ which may be adjusted (or not) by expert evaluators considering potentially important factors not included in the actuarial measure. ${ }^{97}$

91. In re Young, 857 P.2d 989, 1017 (Wash. 1993) (en banc), superseded by statute, WASH. REV. CODE $\S 71.09 .010-.903$ (2014), as recognized in In re Thorell, 72 P.3d 708, 720-21 (Wash. 2003) (en banc). See generally supra text note 25 .

92. In re Holtz, 653 N.W.2d 613, 619 (lowa Ct. App. 2002) (concluding that if scientific, technical, or other specialized knowledge will assist the trier of fact to understand the evidence or to determine a fact in issue, a witness qualified as an expert by knowledge, skill, experience, training, or education may testify).

93. See In re Burton, 884 So. 2d 1112, 1119 (Fla. Dist. Ct. App. 2004) (Altenbernd, C.J., concurring) (discussing the use of actuarial instruments in predicting future human behavior in violent sex offenders).

94. See, e.g., Dennis M. Doren, Evaluating Sex Offenders: A Manual for Civil COMMITMENTS AND BEYOND 104 (2002).

95. Id.

96. Id. at 105 .

97. Id. 
Courts must contend with finding the correct standard that balances the potential for unfair prejudice against the evidence's probative value. ${ }^{98}$ In spite of the knowledge that testimony predicting the future dangerousness of a person who has been convicted of a sexual offense is undoubtedly prejudicial, some courts have deemed actuarial assessments as appropriate tools that help the professional draw inferences about the potential for recidivism from historical data, or the collective experience of other professionals who have assessed sex offenders for potential recidivism. ${ }^{99}$ Courts have held that the adversarial protections of crossexamination and rebuttal witnesses would sufficiently allow the defendant the opportunity to challenge actuarial instruments' validity. ${ }^{100}$ This, of course, is only effective if the defendant is afforded an opportunity for a rebuttal witness, and has been assigned effective counsel who is knowledgeable and able to dispute the assigned level of risk. ${ }^{101}$

In a thorough and probing analysis of these tests, Professors Eric Janus and Robert Prentky have concluded that, "to a greater or lesser extent, all ARA ["actuarial risk assessment"] instruments have shortcomings, and these shortcomings detract from the reliability of the instruments." 102 The authors note that there are three potential sources of prejudice from ARA testimony: first, that the scientific and statistical nature of actuarial assessments will unduly influence the fact-finder into giving it more weight and credibility than it deserves, and that the principle of "actuarial superiority" will exacerbate this tendency; second, that juries will ignore

98. See generally In re Burton, 884 So. 2d 1112, 1115-17 (analyzing, under the Frye standard, the use of psychometric tests to determine future dangerousness of people convicted of sex crimes).

99. See, e.g., Arizona ex rel. Romley v. Fields, 35 P.3d 82, 89 (Ariz. Ct. App. 2001) (admitting actuarial assessments into evidence, but noting that "[u]nlike DNA and other types of 'scientific' evidence, these risk assessment tools do not have an aura of scientific infallibility ... and their predictive value is far less than $100 \%$.").

100. E.g., In re Erbe, 800 N.E.2d 137, 155 (Ill. App. Ct. 2003); see also Barefoot v. Estelle, 463 U.S. 880, 901 (1983) ("We are unconvinced, however, at least as of now, that the adversary process cannot be trusted to sort out the reliable from the unreliable evidence and opinion about future dangerousness"); Halleck v. Coastal Bldg. Maint. Co., 647 N.E.2d 618, 627 (Ill. App. Ct. 1995) ("On cross-examination, counsel may probe an expert witness' qualifications, experience and sincerity, the weaknesses in the basis of his opinions, the sufficiency of his assumptions, and the general soundness of his opinion.") (citation omitted).

101. This issue was explored in In re Linehan, 557 N.W.2d 171 (Minn. 1996), an early case involving an individual committed under Minnesota's SVP law, in which the defendant, represented by competent counsel, challenged his commitment because the state's expert had failed to use actuarial methods in his risk assessment. $I d$. at 189 . The defendant unsuccessfully argued that by failing to perform actuarial analysis, the state had ignored "state of the art" evidence and the "best available scientific knowledge and methodology." Id. The case was later vacated on other grounds sub nom. Linehan v. Minnesota, 522 U.S. 1011 (1997).

102. Eric S. Janus \& Robert A. Prentky, Forensic Use of Actuarial Risk Assessment with Sex Offenders: Accuracy, Admissibility and Accountability, 40 AM. CRIM. L. REV. 1443, 1472 (2003). 
the lack of "fit" between the actuarially-derived risk and the legally relevant risk, thus giving ARA too much weight; and third, that the reality that the "incriminating significance" of statistical probabilities is "obscure." 103

The end result is the assignment of a corresponding number or value to the individual being evaluated. ${ }^{104}$ This number signifies either high or low risk of reoffending and becomes, in essence, a "scarlet number" that is comparable to the shaming methods behind the assignment of a "scarlet letter" used to humiliate or draw public ridicule to women deemed unchaste. ${ }^{105}$ If the assigned risk level generated by an actuarial tool is high, it attaches to the individual and is used to justify commitment year after year. ${ }^{106}$ The person is reduced to a statistic, and labeled as another high-risk offender unworthy of liberty and freedom. ${ }^{107}$ This is directly related to shame and humiliation. ${ }^{108}$ This impression of a dangerous recidivist sticks despite unanswered questions as to the ethical usage and accuracy of these predictive instruments. ${ }^{109}$

\section{B. Evidence-Induced Humiliation}

In addition to the stigma and shame associated with the actuarial tool assigned number, sex offender commitment proceedings in and of themselves include a handful of lax evidentiary rules that can further contribute to the individual feeling shame and humiliation during the

103. Id. at 1487.

104. Two of the most commonly used actuarial prediction tools in SVP determinations are the Rapid Risk Assessment for Sex Offence Recidivism (RRASOR) and STATIC-99. See Fred S. Berlin et al., The Use of Actuarials at Civil Commitment Hearings to Predict the Likelihood of Future Sexual Violence, 15 SEXUAL ABUSE: J. RES. \& TREATMENT 377, 378 (2003).

105. NathaNiEL HAWTHORNE, THE SCARLET LETTER (1850).

106. See In re K.S., No. A-1451-07T2, 2008 N.J. Super. Unpub. LEXIS 627, at *6-9 (N.J. Super. Ct. App. Div. Mar. 11, 2008) (noting "high risk" score on STATIC-99 as part of determination that commitment was proper); R. Karl Hanson et al., High-Risk Sex Offenders may not be High Risk Forever, 29 J. INTERPERSONAL INT'L VIOLENCE 2792 (2014). The median year of release was 1996; the release year ranged from 1957 to 2007. Hanson et al., supra 106, at 2798 tbl.1.

107. See, e.g., Perlin \& Weinstein, supra note 31 , at 2 (discussing a trial judge in one sex offender case who said, about persons who molest children, "It is my feeling that we should probably dye them green" (citing Leonore H. Tavill, Scarlet Letter Punishment: Yesterday's Outlawed Penalty Is Today's Probation Condition, 36 CLEv. ST. L. REv. 613, 644 n.193 (1988)).

108. This can be compared with the high-risk label generated by community registration tier levels, see Doe v. Pataki, 3 F. Supp. 2d 456, 467-68 (S.D.N.Y. 1998) (stating that information provided to the community through the New York Sex Offender Registration Act carries with it "shame, humiliation, ostracism, loss of employment and decreased opportunities for employment, perhaps even physical violence").

109. See In re Burton, 884 So.2d 1112, 1120 (Fla. Dist. Ct. App. 2004) (Altenbernd, C.J., concurring) ("I, for one, do not yet have faith that it is wise for the judiciary or for society as a whole to rush down this new path before we are confident that both the science of jurisprudence and the sciences of psychology and psychiatry are up to this awesome task."). 
trial.

A broad spectrum of documents and otherwise inadmissible hearsay can be admitted into evidence at an SVP trial if the testifying expert relied on that information in formulating an opinion. ${ }^{110}$ The courts frequently refer to the "professional reliability" exception for expert testimony as the professional reliability exception to the rule against hearsay. ${ }^{111} \mathrm{~A}$ testifying expert will consider both convictions and charges during their evaluation, and mental health professionals often rely on charged conduct that has not resulted in a final determination of guilt, especially if those charges further support an antisocial personality disorder. ${ }^{112}$ Hearsay evidence, otherwise inadmissible, will be considered as long as an expert accurately testifies that the relied upon materials are the types of materials reasonably relied on to diagnose future dangerousness of sex offenders. ${ }^{113}$ The Kansas court in In re Crane ${ }^{114}$ held that:

"We are hard-pressed to see how such evidence can be prohibited [in sexually violent predator cases] when it is an essential element of the required proof and necessary for the decision-making process of the jury." 115 Therefore, prior acts that never in fact occurred or occurred differently from what is detailed in police and/or experts' reports - are presented in open court to further compound the "evil" or "bad" image of the defendant.

Examples of hearsay that have been accepted in SVPA proceedings include:

The defendant's complete criminal history, including non-sexual prior crimes; ${ }^{116}$

Prior convictions without proving any constitutional validity in appropriate circumstances; ${ }^{117}$

110. In re T.J.N., 915 A.2d 53, 57 (N.J. Super. Ct. App. Div. 2007) (explaining that the trial court could consider hearsay referred to in expert's report).

111. People v. Campbell, 602 N.Y.S.2d 282, 284 (N.Y. App. Div. 1993) (defense psychiatric testimony offered to prove involuntariness of defendant's admission and not for the truth of defendant's statements to the psychiatrist).

112. Commonwealth v. Garrett, 667 S.E.2d 739, 749 (Va. 2008). The Virginia Supreme Court distinguished this reliance as being legally insufficient when the charges have been dismissed and in absence of other evidence, an expert still relies on them. Id. See also Tamara Rice Lave \& Aviva Orenstein, Empirical Fallacies of Evidence Law: A Critical Look at the Admission of Prior Sex Crimes, 81 U. CIN. L. REv. 795 (2013) (criticizing rules permitting the admission of evidence that defendants have committed prior sexual misconduct).

113. In re Colt, 211 P.3d 797, 801-02 (Kan. 2009) (nonsexual prior crimes may be both probative and material of certain diagnoses and behavior patterns and thus relevant).

114. In re Crane, 7 P.3d 285 (Kan. 2000), vacated on other grounds by Kansas v. Crane, 534 U.S. 407 (2002).

115. In re Crane, 7 P.3d at 293.

116. In re Colt, 211 P.3d at 801-02.

117. State v. Ammons, 718 P.2d 796 (Wash. 1986), cert. denied, Ammons v. Washington, 479 U.S. 930 (1986). 
Evidence that was never adjudicated in a court of law; 118

Consideration of criminal charges that were acquitted; ${ }^{119}$ Reliance on juvenile criminal records. ${ }^{120}$

Skewing the rules of hearsay and allowing the court or jury to hear expert testimony on potentially false or untrue information is directly linked to humiliation and exemplifies "an interaction in which one is debased or forced into a degraded position by someone who is, at that moment, more powerful." 121

\section{Shame in and out of Treatment}

\section{In Treatment}

Once an individual enters sex offender civil commitment, the focus is ostensibly no longer punishment but is, rather, containment with an emphasis on treatment. ${ }^{122}$ Some states require eligible sex offenders to participate in treatment. ${ }^{123}$ In other states, where treatment is "voluntary," heavy penalties, sanctions and the threat of incarceration directly influence and individual's decision to participate. ${ }^{124}$ Many of the practices common in the treatment of sex offenders elicit shame, but this reality is often not recognized or dealt with in treatment. ${ }^{125}$ The coercive environment of sexual violent predator treatment cannot be overstated, ${ }^{126}$

118. In re Frankovitch, 121 P.3d 1240, 1245 (Ariz. Ct. App. 2005), review denied (2006) (criminal history admissible in hearing; inmate had no right to confrontation).

119. In re Stout, 150 P.3d 86 (Wash. 2007) (state not estopped from introducing evidence of incident for which inmate had been acquitted of attempted rape).

120. Commonwealth v. Garrett, 667 S.E.2d 739, 749 (Va. 2008) (concluding that the trial court could exclude diagnosis of "Paraphilia, Not Otherwise Specified ... Sexual Abuse of Child," due to expert's improper reliance on juvenile petitions that were dismissed nolle prosequi).

121. Hartling \& Luchetta, supra note 66, at 262 (citing Miller, supra note 66).

122. See Margaret Campbell, Sex Offender Notification Laws: Should They Provide Treatment Incentives for Sex Offenders?, 20 DEVEL. IN MENTAL HEALTH L. 1 (2001); Eric Janus \& Wayne A. Logan, Substantive Due Process and the Involuntary Confinement of Sexually Violent Predators, 35 CONN. L. REv. 319, 349 (2003).

123. Michael L. Prendergast et al., Involuntary Treatment within a Prison Setting: Impact on Psychosocial Change During Treatment, 29 Crim. Just. \& BeHAV. 5, 9 (2002).

124. NEB. REv. StAT. $\S 71-1202$ (2016) (it is "public policy" that dangerous sex offenders obtain voluntary treatment; however, if "voluntary treatment is not obtained, such persons shall be subject to involuntary custody and treatment.").

125. See, e.g., Anne-Marie McAlinden, The Use of "Shame" with Sexual Offenders, 45 BRIT. J. CRIMINOL. 373, 374 (2005).

126. Mary West et al., Colo. Dep't of Corrections, State Sex Offender Treatment Programs 19 (2000) (refusal to attend treatment or denial of offenses on the part of sex offender may affect parole decisions or result in negative consequences); Wirsching v. Colorado, 360 F.3d $1191,1193,1205$ (10th Cir. 2004) (appellant must participate in a treatment program or forego visitation privileges and the opportunity to earn good time credits); United States v. Antone, 742 F.3d 151, $171 \mathrm{n} .17$ (4th Cir. 2014) (attendance and success in sex offender therapy has a potential impact on future civil commitment hearings). 
and "the stakes for refusing to [participate] are so high that participation in treatment is almost compulsory." $" 27$ Many clinicians believe that an offender must take responsibility and admit to all offenses (charged and uncharged) in order for treatment to be beneficial and effective. ${ }^{128}$ During treatment, participants must confess to any crimes listed in previous documents and admissions may be used against the participant in future court proceedings. ${ }^{129}$ If someone's potential liberty is dependent upon taking responsibility for crimes or events that never happened, he or she would most certainly experience shame through the "downward redefinition of oneself." ${ }^{30}$ Furthermore, being forced to agree with inaccurate or untrue portions of an offending history could elicit behavioral responses to shame, such as hiding, avoidance and masking the source of shame ${ }^{131}$ - that might very well prevent the beneficial goal of getting to the "truth of the matter" in offending behaviors. ${ }^{132}$ Nothing so clearly violates "the dignity of persons as treatment that demeans or humiliates them" as shaming. ${ }^{133}$ Some experts have claimed that shame is the cause, rather than the effect, of many sex offenses. ${ }^{134}$

Examples of treatment protocols that have the potential to elicit shame are:

1. the preparation of a detailed timeline and autobiography,

2. the detailed processing of crimes through the construction of a

127. See Hydrick v. Hunter, 466 F. 3d 676, 693 (9th Cir. 2006), superseded by, 500 F.3d 978 (9th Cir. 2007), vacated by, 129 S. Ct. 3241 (2009).

128. See Robert J. McGrath et al., Cognitive-Behavioral Treatment of Sex Offenders: A Treatment Comparison and Long-Term Follow-Up Study, 25 CRIM. JUST. \& BEHAV. 203, 211 (1998) (a crucial initial step in cognitive behavioral therapy is for sex offenders to admit and then give a full disclosure of their offense to the treatment group); see also Anita Schlank \& Rick Harry, The Treatment of the Civilly Committed Sex Offender in Minnesota: A Review of the Past Ten Years, 29 WM. MiTCHELL L. REV. 1221, 1224 (2003) ("most treatment providers believe that rehabilitation begins with acceptance of responsibility").

129. See generally Anita M. Schlank \& Theodore Shaw, Treating Sexual Offenders Who Deny Their Guilt: A Pilot Study, 8 SeXUAl ABUSE: J. Res. \& TREATMENT 17, 18 (1996) (first goal of therapy is to help the perpetrator acknowledge that he has a problem); see also WASH. STATE Inst. For Pub. Policy, Sex Offender Sentencing In Washington State: Who Participates IN THE PRISON TREATMENT PROGRam 3 (2006) ("[T] he law could motivate some sex offenders to decline participation because revelations during their treatment about additional victims or violence could later be used as reasons for the state to file a Sexually Violent Predator petition.").

130. Massaro, Shame, Culture, and American Criminal Law, supra note 34, at 1901.

131. See generally id. at 1899.

132. See generally Fletcher, supra note 51, at 16.

133. R. George Wright, Dignity and Conflicts of Constitutional Values: The Case of Free Speech and Equal Protection, 43 SAN Diego L. REv. 527, 549 (2006).

134. See Jackie Craissati et al., Characteristics of Perpetrators of Child Sexual Abuse Who Hove Been Sexually Victimized as Children, 14 Sexual AbuSE: J. Res. \& TREATMEnT 225, 227 (2000). 
behavior chain, ${ }^{135}$

3 . the requirement that offenders confront their own history of abuse.

4. phallometric assessment, ${ }^{136}$ and

5. the requirement that offenders write, but not send, letters to victims. $^{137}$

Shame is likely to be elicited repeatedly in sex offender treatment and individuals might experience feelings of low self-esteem, worthlessness, being defective or empty inside, and feeling unlovable. ${ }^{138}$ The therapist must be able to anticipate, recognize, and know how to deal with the fallout from shame in order to prevent individuals from becoming overwhelmed. ${ }^{139}$ An important part of this is to establish a "culture of treatment" 140 so that "the client will not perceive himself or herself to be criticized, humiliated, rejected, dramatically misunderstood, needlessly interrupted, or laughed at during therapy. ${ }^{141}$

Even if participants fully immerse themselves in the treatment process, completion of treatment does not correlate with release from commitment. ${ }^{142}$ Being denied the rewards of treatment success would undoubtedly result in a lack of dignity and a reduction in intrinsic worth. ${ }^{143}$ When the supposedly holistic and therapeutic goal of treatment is infused with shame, humiliation and lack of dignity, the prevalence of treatment-inhibiting mental health concerns such as depression, paranoia,

135. James Vess, Risk Formulation with Sex Offenders: Integrating Functional Analysis and Actuarial Measures, $1 \mathrm{~J}$. BEHAV. ANALYSIS OFFENDER AND VICTIM TREATMENT AND PREVENTION 29, 37 (2008) (behavior chain analysis involves an in-depth understanding of events and situational factors before and after instances of the problem behavior).

136. Many researchers have come to believe that it is possible to measure scientifically a person's sexual desire by placing a pressure-sensitive device around a man's penis, presenting him with an array of sexually stimulating images, and determining his level of sexual attraction by measuring minute changes in his erectile responses. See, e.g., Jason R. Odeshoo, Of Penology and Perversity: The Use of Penile Plethysmography on Convicted Child Sex Offenders, 14 TEMP. POL. \& Civ. RTS. L. REV. 1, 2 (2004); see generally John Fabian, The Risky Business of Conducting Risk Assessments for Those Already Civilly Committed as Sexually Violent Predators, 32 WM. Mitchell L. REV. 81, 136 (2005).

137. Jay Adams, Sex Offender Treatment: The Brain, Attachment Theory, and Trauma Processing [hereinafter Adams, Sex Offender Treatment]; see also, Jay Adams, Expanding Sex Offender Treatment, CALIFORNIA COALITION ON SEXUAL OFFENDING, https://ccoso.org/featuredarticles [hereinafter Expanding Sex Offender Treatment].

138. Adams, Sex Offender Treatment, supra note 137; Expanding Sex Offender Treatment, supra note 137.

139. Id.

140. Id.

141. Id.

142. Jeslyn A. Miller, Sex Offender Civil Commitment: The Treatment Paradox, 98 CALIF. L. REV. 2093, 2117 (2010).

143. See generally Ploch, supra note 74, at 895-96. 
violence, anxiety, and suicide, can be especially strong and pervasive. ${ }^{144}$

\section{Out of Treatment}

For an individual to succeed in treatment while committed as an SVP, he must fully participate, potentially disclosing certain information that may be harmful to his legal case. ${ }^{145}$ Clinicians working in the institutions are "required to resolve ethical dilemmas, which invariably arise ... by breaching traditional mental health ethical principles such as maintaining confidentiality and promoting patient autonomy." 146 A limited right of privacy attaches to psychiatric evaluations and statements made in the course of treatment. ${ }^{147}$ "[S] exually violent predator evaluations fall within two established exceptions to the confidentiality of medical communications: the exception for public health and safety, ${ }^{148}$ and the exception for communications made to a physician for a potential adversary's purpose rather than for curative treatment." 149 Some courts have held that the psychotherapist-patient privilege never attaches in sex offender treatment, because medical examinations are not intended to be confidential. $^{150}$

The American Academy of Psychiatry and Law has voiced its concerns about such court-ordered evaluations: "Respect for the individual's right of privacy and the maintenance of confidentiality are major concerns ... [p]sychiatrists should maintain confidentiality to the extent possible, given the legal context." ${ }^{151}$ Regardless, courts have found that information elicited during treatment could be used in involuntary

144. Fiske, supra note 67, at 78 (citing Donald C. Klein, The Humiliation Dynamic: An Overview, 12 J. Primary Prevention 93, 107-12 (1991)).

145. Beaulieu v. Ludeman, 690 F.3d 1017, 1026 (8th Cir. 2012), distinguished by Arnzen v. Palmer, 713 F.3d 369 (8th Cir. 2013); In re Colt, 211 P.3d 797, 801 (Kan. 2009) (citing In re Crane, 7 P.3d 285, 294 (Kan. 2000) ("[E]vidence of prior conduct [is] material to the question of likelihood that the respondent would engage in repeat conduct as well as to the element of conviction of prior conduct")); see generally Jana R. McCreary, Not Guilty .. . Until Recommitment: The Misuse of Evidence of the Underlying Crime in NGRI Recommitment Hearings, 2009 UTAH L. REv. 1253, 1258 (2009).

146. Bill Glaser, Therapeutic Jurisprudence: An Ethical Paradigm for Therapists in Sex Offender Treatment Programs, 4 W. CRIM. REv. 143 (2003).

147. Seaton v. Mayberg, 610 F.3d 530, 534 (9th Cir. 2010) (privacy right overridden by legitimate penological reason).

148. See Isaac D. Buck, The Indefinite Quarantine: A Public Health Review of Chronic Inconsistencies in Sexually Violent Predator Statutes, 87 SAINT JOHN's L. ReV. 847, 850 (2013).

149. Miller, supra note 142, at 2109.

150. See, e.g., People v. Martinez, 105 Cal. Rptr. 2d 841, 853 (Ct. App. 2001); In re No. MH 1717-1-85, 721 P.2d 142, 144 (Ariz. Ct. App. 1986); In re Deville, 610 So. 2d 1070, 1072 (La. Ct. App. 1992) (physician-patient privilege did not apply to bar admission of mental patient's medical records or oral testimony of treating physician).

151. American Academy of Psychiatry and law, Ethical Guidelines for the Practice of Forensic Psychitrit, Am. ACad. Psychiatry \& Law (May 2005), http://www.aapl.org/ethics-guidelines.). 
civil commitment proceeding, and that information garnered during treatment while in prison was admissible in initial hearing to determine SVP status. ${ }^{152}$

The shame in retelling prior sexual crimes in a closed, supposed treatment oriented setting is further compounded by humiliation when those shameful thoughts, acts and behaviors are retold in court due to a lack of therapist-patient confidentiality. This lack of confidentiality would surely decrease trust in the therapeutic process and lead to failures in treatment. It is the antithesis of "a process that [would allow] them to participate, ... merit their trust, and treat[] them with dignity and respect." 153

Scholars have considered whether the emotions of shame and guilt can represent a critical "stepping stone" in the rehabilitation process. ${ }^{154}$ There is a significant distinction between feeling shame and guilt; shame arises from a negative focus on the self-one's core identity, while guilt arises from a negative focus on a specific behavior. ${ }^{155}$ "[S] hame and guilt refer to related but distinct negative 'self-conscious' emotions. Although both are unpleasant, shame is the more painful self-focused emotion linked to hiding or escaping. Guilt, in contrast, focuses on the behavior and is linked to making amends." 156 Most of the research argues strongly against "shaming" sentences designed to shame and humiliate offenders. ${ }^{157}$ In fact,

shame is associated with outcomes directly contrary to the public interest -- denial of responsibility, substance abuse, psychological symptoms, predictors of recidivism and recidivism itself. Judges seeking creative alternative types of sentences might instead consider sanctions designed to foster constructive feelings of guilt by focusing offenders on the negative consequences of their

152. In re McHoul, 833 N.E.2d 1146 (Mass. 2005), cert. denied, 547 U.S. 1114 (2006) (upholding the admissibility of out-of-court statements made by petitioner to others, observations of petitioner's conduct made by others and on which the experts based their opinions, "group notes" and annual treatment reports, and "observation and behavior reports," notwithstanding the fact that they contained hearsay).

153. Luther T. Munford, The Peacemaker Test: Designing Legal Rights to Reduce Legal Warfare, 12 HARV. NEGOT. L. REV. 377, 393 (2007).

154. June Price Tangney et al., Shame, Guilt and Remorse: Implications for Offender Populations, 22 J. FORENSIC PsYCHIATRY \& PsYCHOL. 706, 706. The treatment literature offers only a few explicitly shame-focused, manualized therapies. See, e.g., PATrick GilberT, Compassion Focused Therapy: The Distinctive Features 26 (2017); Shireen L. Rizvi \& Marsha M. Linehan, The Treatment of Maladaptive Shame in Borderline Personality Disorder: A Pilot Study of "Opposite Action," 12 Cognitive. \& Behav. Prac., 437, 437 (2005); Brene Brown, ConNections: A 12-Session PsychoeduCATIONAL Shame Resilience CuRriculum 2 (2d ed. 2009).

155. Tangney et al., supra note 154 , at 707.

156. Id. at 708 .

157. Id. at 716 . 
behavior. ${ }^{158}$

Instead, the goal should be to enhance "offenders' capacity to experience 'shame-free' guilt about harmful actions past, present, and anticipated future."159

\section{Absence of Dignity in the Courtroom}

The criminally based principles of individual dignity, "generally articulated through concepts of autonomy, respect, equality, and freedom from undue government interference," context of sex offenders in civil proceedings.

Perceptions of systemic fairness are driven, in large part, by "the degree to which people judge that they are treated with dignity and respect." $" 161$ The U.S. Supreme Court has recognized that legislative enactments can result in humiliating consequences, and has underscored dignity's important role in the law. ${ }^{162}$ In several landmark decisions, the Court has struck down both criminal and civil statutes that humiliate and shame the defendants. ${ }^{163}$ With these cases, the Court has acknowledged the importance of the role of dignity. ${ }^{164}$ Elsewhere, the Court has specifically recognized the shame that can result when dignity is not present. In Indiana v. Edwards, the Court held that "a right of selfrepresentation at trial will not 'affirm the dignity' of a defendant who lacks the mental capacity to conduct his defense without the assistance of counsel." 165 The Court stated, "in the contrary, given that defendant's

158. Id.

159. Id. at 717 .

160. Miller, supra note 76, at $1570-71$ n.473.

161. Tom R. Tyler, The Psychological Consequences of Judicial Procedures: Implications for Civil Commitment Hearings, 46 SMU L. REV. 433, 442 (1992), discussed in Michael L. Perlin, A Law of Healing, 68 U. CIN. L. REV. 407, 415 (2000). See also Norman G. Poythress, Procedural Preferences, Perceptions of Fairness, and Compliance with Outcomes, 18 LAW \& HUM. BEHAV. 361, 361 (1994); P. Christopher Earley \& E. Allan Lind, Procedural Justice and Participation in Task Selection: The Role of Control in Mediating Justice Judgments, 52 J. PERSONALITY \& SOC. PSYCHOL. 1148, 1159 (1987).

162. See Jones v. Barnes, 463 U.S. 745, 759 (1983) (Brennan, J., dissenting) (stating that one of the critical functions of counsel in the trial process is to "protect the dignity and autonomy of a person on trial ...").

163. This is not to say that this line of decisions is unanimous. See, e.g., Florence v. Bd. of Chosen Freeholders, 132 S. Ct. 1510, 1523 (2012) (holding that suspicion-less strip searches of detainees being admitted to the general jail population did not violate the Fourth or Fourteenth Amendments); Julian Simcock, Florence, Atwater, and the Erosion of Fourth Amendment Protections for Arrestees, 65 STAN. L. REv. 599, 601-02 (2013) (detailing how decisions such as Florence may heighten the potential risk of abuse by prison officials).

164. E.g., Lawrence v. Texas, 539 U.S. 558, 574-75 (2003).

165. Indiana v. Edwards, 554 U.S. 164, 176 (2008) (citing McKaskle v. Wiggins, 465 U.S. 168, 176-77 (1984) (finding a pro se defendant's Sixth Amendment right to conduct his own defense was not violated by unsolicited participation of standby counsel)). 
uncertain mental state, the spectacle that could well result from his selfrepresentation at trial is at least as likely to prove humiliating as ennobling." 166 The preservation of dignity is without a doubt, an important aspect of our legal system, yet when that system includes sex offenders, dignity is often absent.

Judicial integrity is the first step to preserving dignity. Judges have by and large, "bought into" myths about the high recidivism rates of sex offenders, ${ }^{167}$ and the need for sex offender laws in order to protect the general public. ${ }^{168}$ An individual facing sex offender civil commitment, will probably experience some lack of dignity due to the circumstances that brought them before the court, but the improper conduct of judges, based primarily on their disgust and/or misconceptions of those labeled sexual predators, can contribute to that person's complete loss of dignity. Pretextual devices such as condoning perjured testimony, distorting appellate readings of trial testimony, subordinating statistically significant social science data, and enacting purportedly prophylactic civil rights laws that have little or no "real world" impact dominate the mental disability law landscape. ${ }^{169}$ Judges in mental disability law cases often take relevant literature out of context, ${ }^{170}$ misconstrue the data or evidence being offered, ${ }^{171}$ and/or read such data selectively, ${ }^{172}$ and/or inconsistently. ${ }^{173}$ Other times, courts choose to flatly reject this data or ignore its existence. ${ }^{174}$ In other circumstances, courts simply "rewrite" factual records so as to avoid having to deal with social science data that is cognitively dissonant with their view of how the world "ought to be."175

166. Id. at 176; see generally Perlin \& Weinstein, supra note 31 , at 11-18.

167. See PERLIN \& CUCOLO, supra note 80, at 166. See also Ira Mark Ellman \& Tara Ellman, "Frightening and High": The Supreme Court's Crucial Mistake about Sex Crime Statistics, 30 CONST. COMMENT. 495, 496 (2015).

168. See, e.g., Bruce J. Winick, Foreword: Therapeutic Jurisprudence Perspectives on Dealing with Victims of Crime, 33 Nova L. REV. 535 (2009) (discussing the "small" likelihood of a judge ever overruling a prosecutor's discretionary determination in such cases).

169. Michael L. Perlin, "There's No Success like Failure/and Failure's No Success at All": Exposing the Pretextuality of Kansas v. Hendricks, 92 Nw. U. L. REv. 1247, 1256 (1998).

170. David Faigman, "Normative Constitutional Fact-Finding": Exploring the Empirical Component of Constitutional Interpretation, 139 U. PA. L. REV. 541, 577 (1991).

171. Id. at 581 .

172. J. Alexander Tanford, The Limits of a Scientific Jurisprudence: The Supreme Court and Psychology, 66 IND. L.J. 137, 153-54 (1990).

173. See, e.g., Thomas Hafemeister \& Gary Melton, The Impact of Social Science Research on the Judiciary, in REFORMING THE LAW: IMPACT OF CHILD DEVELOPMENT RESEARCH 27 (Gary Melton ed., 1987).

174. See, e.g., Barefoot v. Estelle, 463 U.S. 880, 897-902 (1983), discussed in PERLIN, supra note 4 , at $21-26$.

175. The classic example is Chief Justice Burger's opinion for the court in Parham v. J.R. 442 U.S. 584, 605-10 (1979) (approving more relaxed involuntary civil commitment procedures for juveniles than for adults), critiqued in, inter alia, Gail Perry \& Gary Melton, Precedential Value of Judicial Notice of Social Facts: Parham as an Example, 22 J. FAM. L. 633, 633-34 (198384), and Michael L. Perlin, An Invitation to the Dance: An Empirical Response to Chief Justice 
A proceeding that is fundamentally unfair and heavily weighted against the defendant due to erroneous rulings by the fact-finder, will have a negative effect on dignity and potentially provoke feelings of hopelessness, unworthiness, and being regarded as "less than human."176 This pretextual behavior by judges mocks constitutional requirements of dignity and is of no benefit to either the offender or the community. ${ }^{177}$

\section{E. How Attorneys can Combat Client Feelings of Shame, Humiliation and Lack of Dignity}

\section{The Sanist Attorney}

Sanism is an irrational prejudice of the same quality and character of other irrational prejudices that cause (and are reflected in) prevailing social attitudes of racism, sexism, homophobia, and ethnic bigotry. ${ }^{178} \mathrm{It}$ infects both our jurisprudence and our lawyering practices. Sanism is largely invisible and largely socially acceptable. ${ }^{179}$ It is based predominantly upon stereotype, myth, superstition, and deindividualization, and is sustained and perpetuated by our use of alleged "ordinary common sense" (OCS) and heuristic reasoning in an unconscious response to events both in everyday life and in the legal process. ${ }^{180}$ It reflects the assumptions that are made by the legal system

Warren Burger's "Time-Consuming Procedural Minuets" Theory in Parham v. J. R., 9 J. AM. ACAD. PSYCHIATRY \& LAW 149, 151 (1981); see generally Perlin \& Lynch, Nobody's Child, supra note 46.

176. Abril R. Bedarf, Examining Sex Offender Community Notification Laws, 83 CALIF. L. REv. 885, 910 (1995) (explaining that community notification jeopardizes an offender's ability to reintegrate into society and lead a productive life).

177. On how civil commitment threatens a person's liberty and dignity with "equally drastic consequences as those associated with criminal prosecutions," see People v. Hurtado, 124 Cal.Rptr.2d 186 (2002), as discussed in Meehan Rasch, California's Dueling Harmless Error Standards: Approaches to Federal Constitutional Error in Civil Proceedings and Establishing the Proper Test for Dependency, 35 W. ST. U. L. REV. 433, 447-48 (2008).

178. Michael L. Perlin, "They Keep It All Hid": The Ghettoization of Mental Disability Law and Its Implications for Legal Education, 54 ST. LoUs U. L. J. 857, 860-61 (2010).

179. Michael L. Perlin, "Everybody Is Making Love/Or Else Expecting Rain": Considering the Sexual Autonomy Rights of Persons Institutionalized Because of Mental Disability in Forensic Hospitals and in Asia, 83 WASH. L. REV. 481, 486 (2008).

180. See Michael L. Perlin, "Half-Wracked Prejudice Leaped Forth": Sanism, Pretextuality, and Why and How Mental Disability Law Developed as It Did, 10 J. CONTEMP. LEGAL ISSUES 3, 3 (1999). "Heuristics" is a cognitive psychology construct that refers to the implicit thinking devices that individuals use to simplify complex, information-processing tasks." Michael L. Perlin, The Sanist Lives of Jurors in Death Penalty Cases: The Puzzling Role of "Mitigating" Mental Disability Evidence, 8 Notre DaMe J.L. ETHICs \& PUB. POL'Y 239, 254 (1994). "[O]rdinary common sense" is a "prereflective attitude' exemplified by the attitude of 'What I know is self-evident'; it is 'what everybody knows." Keri K. Gould \& Michael L. Perlin, "Johnny's in the Basement/Mixing Up His Medicine": Therapeutic Jurisprudence and Clinical Teaching, 24 SEATtLE U. L. REV. 339, 357 (2000) (citing Richard K. Sherwin, Dialects and Dominance: A Study of Rhetorical Fields in the Law of Confessions, 136 U. PA. L. REV. 729, 737 
about persons with mental disabilities - who they are, how they got that way, what makes them different, what there is about them that lets society treat them differently, and whether their condition is immutable. ${ }^{181}$ These assumptions - that reflect societal fears and apprehensions about mental disability, persons with mental disabilities ${ }^{182}$ and the possibility that any individual may become mentally disabled ${ }^{183}$-ignore the most important question of all - why do we feel the way we do about people with mental disabilities? ${ }^{184}$

"Sanist attitudes lead to pretextual decisions." "Pretextuality" means that courts accept (either implicitly or explicitly) testimonial dishonesty and engage similarly in dishonest (and frequently meretricious) decisionmaking, specifically where witnesses, especially expert witnesses, show a high propensity to purposely distort their testimony in order to achieve desired ends. ${ }^{185}$ This pretextuality is poisonous; it infects all participants in the judicial system, breeds cynicism and disrespect for the law, demeans participants, and reinforces shoddy lawyering, blasé judging, and, at times, promotes perjurious and/or corrupt testimony." 186 The issues are compounded when we consider the component of sexual offending. Lawyers have their own opinions, prejudices, emotional responses and personality conflicts that might no doubt be tested in the

(1988)).

181. See, e.g., Martha Minow, MAKIng All the DifFerence: InClusion, ExClusion, AND american law (1990); Sander Gilman, DifFerence and Pathology: Stereotypes of SEXUALITY, RaCE and MADNEss (1985). On how laws regulating sex offenders are part of a tradition "of laws targeting 'out' groups in society," see BERNADETTE M. MCSHERRY \& PATRICK Keyzer, Sex Offenders and Preventive Detention: Politics, Policy and Practice 37 (2009).

182. See H. Archibald Kaiser, The Convention on the Rights of Persons with Disabilities: Beginning to Examine the Implications for Canadian Lawyers' Professional Responsibilities, 20 Health L. Rev. 26, 30 (2012).

183. See Michael L. Perlin, Competency, Deinstitutionalization, and Homelessness: A Story of Marginalization, 28 Hous. L. REV. 63, 108 (1991) (on society's fears of persons with mental disabilities); "[W] hile race and sex are immutable, we all can become mentally ill, homeless, or both. Perhaps this illuminates the level of virulence we experience here." Id. at $93 \mathrm{n} .174$ (emphasis in original).

184. See, e.g., Marchell Goins et al., Perceiving Others as Different: A Discussion on the Stigmatization of the Mentally Ill, 19 ANNALS HEALTH L. 441, 441-42 (2010). On how sanism is more pernicious than any other stigma, see Matthew Large \& Christopher J. Ryan, Sanism, Stigma and the Belief in Dangerousness, 46 AUST. \& N.Z. J. PSYCHIATRY 1099 (2012).

185. Michael L. Perlin \& Naomi Weinstein, "Said I, 'But You Have No Choice'”: Why a Lawyer Must Ethically Honor a Client's Decision about Mental Health Treatment Even if It Is Not What S/he Would Have Chosen, 15 Cardozo PuB. L., Pol'Y \& ETHICS J. 73, 84-85 (2016/2017) [hereinafter Perlin \& Weinstein, "Said I, 'But You Have No Choice'”]. See, e.g., Michael L. Perlin, "Baby, Look inside Your Mirror": The Legal Profession's Willful and Sanist Blindness to Lawyers with Mental Disabilities, 69 U. PTTT. L. REV. 589, 602 (2008).

186. Perlin \& Weinstein, "Said I, 'But You Have No Choice,"' supra note 185, at 85. See Michael L. Perlin, "Through the Wild Cathedral Evening": Barriers, Attitudes, Participatory Democracy, Professor TenBroek, and the Rights of Persons with Mental Disabilities, 13 TEX. J. ON C.L. \& C.R. 413, 416-17 (2008). 
representation of individuals who committed a sex crime. Although scholarly studies of the effects of "disturbing media" on this population are "relatively recent," 187 researchers have established some very clear findings that have direct relevance to attorney representation. ${ }^{188}$

Litigation in sex offender cases is inherently stressful and emotional, ${ }^{189}$ involving certain identified "emotion-evoking" factors. ${ }^{190}$ In other areas of practice, a lawyer who is unable to gain control over emotional responses to a client might refer the client elsewhere for representation. ${ }^{191}$ But in sex offender commitment cases, referral may be less viable. Clients represented by Legal Aid lawyers or Public Defenders may have nowhere else to go, unless they can be transferred to a different staff attorney in the same office. Thus, in these circumstances, attorneys must insure that the competency of the representation is not compromised by the emotional interference in the lawyer/client relationship. ${ }^{192}$ It is necessary to stress that competency of representation is not a simple definitional phrase. If attorneys allow their emotional responses to interfere in their representation, they are further contributing to the lack of dignity for their client and an undignified legal system. ${ }^{193}$

\section{Overcoming Shame}

Human rights and freedoms are granted to all individuals (including sex offenders) and human rights law provides fundamental protections without qualification or exception. ${ }^{194}$ Clients should be treated as human beings who are legitimately part of the moral and political community and should be acknowledged as both rights-holders and rightsviolators. ${ }^{195}$ It is necessary, in preserving dignity, to acknowledge individuals as persons and not merely as offenders.

187. Jessica Morales, Someone Who Understands: The Effect of Support on Law Enforcement Officers Exposed to Disturbing Media 11 (July 2012) (unpublished M.A. thesis, Minnesota State University, Mankato), http://cornerstone.lib.mnsu.edu/etds/163.

188. Melissa Wells et al., Defining Child Pornography: Law Enforcement Dilemmas in Investigations of Internet Child Pornography Possession, 8 POLICE PRAC. \& Res. 269, 276 (2009) ("Determining whether or not images are explicit or graphic enough to meet the definition of child pornography is a primary dilemma for investigators.").

189. Monica K. Miller et al., Addressing the Problem of Courtroom Stress, 91 JUDICATURE $60,61-66(2008)$.

190. Larry J. Cohen \& Joyce H. Vesper, Forensic Stress Disorder, 25 L. \& PsYCHOL. REV. 1, 17-19 (2001) (describing anxiety symptoms solely attributable to involvement in litigation, which are quite similar to PTSD symptoms).

191. See, e.g., ANDREW S. WATSON, THE LAWYER IN THE INTER VIEWING AND COUNSELING PROCESS 23-24 (1976).

192. Marjorie A. Silver, Love, Hate, and Other Emotional Interference in the Lawyer/Client Relationship, 6 CLINICAL L. REV. 259, 296 (1999).

193. Id.

194. Birgden \& Cucolo, supra note 29 , at 298.

195. Id. at 299-300. 
In sex offender commitment cases, the defense attorney is oftentimes the only person that can offer confidential communications with the client. ${ }^{196}$ Because of this, the attorney may be placed in the position of a pseudo-therapist during client meetings or interviews and preserving a traditional lawyer-client relationship may be especially difficult. ${ }^{197}$ It is necessary for a well-qualified lawyer to be familiar with the language and concepts of mental health law. ${ }^{98} \mathrm{He}$ or she should understand the possible effects of a mental disability or personality disorder on the client, the significance of diagnoses, and the common treatment methods, but needs to be cognizant of overstepping their legal boundaries of representation. ${ }^{199}$ Nonetheless, an attorney can employ certain methods that will not only benefit the legal case, ${ }^{200}$ but also minimize the shame and humiliation that the client may feel in discussing past crimes and current institutional issues.

\section{Judgment is for the Court, not the Attorney}

Although the specific facts involved in these types of cases may elicit opinions and feelings, an attorney needs to refrain from judging their client as either "good" or "bad" and contributing to further humiliation of the individual. It might be necessary for the attorney to have the capacity to separate the act from the individual in order to render competent and effective representation. Value judgments on an individual's character hold no benefit in the analytical processing of the merits of a case and will only further an antagonistic relationship that has the potential to interfere with rigorous representation.

The general principle of condemning the act rather than the actor is in line with John Braithwaite's notion of "reintegrative shame" rather than "stigmatization." Reintegrative shaming treats the offender "as a good person who has done a bad deed," whereas stigmatization treats the offender "as a bad person." ${ }^{201}$ Braithwaite, however, now realizes his point should be modified and made more subtle:

If a man rapes a child or is repeatedly convicted for serious assaults, is it enough for him to feel that he has done a bad act(s) but there is nothing wrong with him as a person? It would seem

196. See generally Miller et al., supra note 189.

197. Id.

198. Id.

199. Jan C. Costello, Representing Children in Mental Disability Proceedings, 1 J. CENTER FOR CHILD. \& COURTS 101, 106 (1999).

200. Donald S. Murphy \& Thomas Schwen, The Future: Transitioning from Training Lawyers to Improving Their Performance, 40 VAL. U. L. REV. 521, 534 (2006).

201. See ohn Braithwaite, Restorative Justice and Therapeutic Jurisprudence, 38 CrIM. L. BuLl. 244, 258 (2002). 
more morally satisfactory for him to feel that he has done a bad act and therefore feels he must change the kind of person he is in some important ways (while still on the whole believing he is basically a good person). That is, we do not want the rapist to believe he is an irretrievably evil person; but we do want aspects of the self to be transformed. ${ }^{202}$

4. "Truth is for the Gods; From our Human Point of View, It is an Ideal, Towards Which We can Approximate, But Which We Cannot Hope to Reach." 203

It is important to remember not to further shame the client by outwardly disbelieving his recollection of past events or his account of current scenarios. In treatment, the client is often disbelieved and verbally attacked by therapists and other treatment group members, ${ }^{204}$ and in court, prosecutors use expert witnesses to find inconsistencies in the client's statements. ${ }^{205}$

\section{5. "Nothing in the World is More Dangerous than Sincere Ignorance and Conscientious Stupidity."206}

How important is it to retain an independent expert in a SVPA proceeding? In order to be an effective advocate at an SVPA hearing, counsel must demonstrate a familiarity with the psychometric tests that are regularly employed at such hearings, ${ }^{207}$ and collaborate with relevant expert witnesses who could assist in the representation of the client, experts who would be appointed by the court at no cost to the person facing sex offender adjudication in the same manner envisioned by the

202. Id. at 259.

203. Bertrand Russell, Freedom versus Authority, in SCEPTICAL ESSAYS 127, 135 (1963).

204. In State v. Mace, 578 A.2d 104 (Vt. 1990), the court ordered an offender's revocation of probation because the offender continued to deny the allegations of sexual intercourse in treatment and despite evidence and testimony to corroborate his claims, his treatment counselor insisted that he was lying and that this was a "stumbling block" to treatment. The writ of habeas was granted and the revocation of probation was vacated sub. nom., Mace v. Amestoy, $765 \mathrm{~F}$. Supp. 847, 852 (D. Vt. 1991).

205. See generally Angela Kebric, Polygraph Testing in Sex Offender Treatment: A Constitutional and Essential Tool for Effective Treatment, 41 ARIZ. ST. L.J. 429 (2009); James M. Shaw, Sex, Lies, and Polygraph Machines: The Portrait of Mr. Cassamassima, 57 U. MIAMI L. REV. 429 (2003).

206. MARTIN LUTHER King JR., StREngth to LOVE 43 (1963).

207. Future risk assessment includes the use of actuarial instruments. See VERNON L. QUINSEY ET AL., VIOLENT OFFENDERS: APPRAISING AND MANAGING RISK 5 (2d ed. 2006); see also Richard Hamill, Recidivism of Sex Offenders: What You Need to Know, 15 CRIM. Just. 24, 30 (2001). 
Supreme Court's Ake v. Oklahoma decision in insanity cases. ${ }^{208}$

The complexities involved in an SVPA trial-mental health determinations, scientific underpinnings, actuarial tests and other scoring tools used by psychologists - all have an impact on whether the quality of representation afforded to individuals facing sexual offender civil commitment is sufficient to protect their liberty interests. ${ }^{209}$ These cases are truly like no other in the justice system, and require a heightened standard of representation. ${ }^{210}$ To meet this heightened standard, counsel must use every resource and tool at his or her disposal in order to be effective and to offer ethical and rigorous representation. Counsel must seek out and have access to expert instruction and opinion on the psychiatric, social and political elements of each case-skills that are most likely beyond most attorneys' schooling and legal education. Without such access, counsel has little hope of understanding the opinions and expertise that he or she will confront. ${ }^{211}$

An independent expert will minimize the effects of shame and humiliation that often accompany these proceedings by (1) showing the client that counsel is taking the case seriously; (2) empowering the client by offering another perspective in a trial that is otherwise weighted so heavily in favor of the prosecution; (3) minimizing the attorney's role as sole confidant and pseudo-therapist; ${ }^{212}$ and (4) educating the attorney so that he or she can be a better advocate for the client in court. ${ }^{213}$

208. Ake v. Oklahoma, 470 U.S. 6880 (1985) (holding that indigent criminal defendant who makes a threshold showing that insanity is likely to be a significant factor at trial is constitutionally entitled to a psychiatrist's assistance). Compare Michael L. Perlin, "And I See Through Your Brain": Access to Experts, Competency to Consent, And the Impact of Antipsychotic Medications in Neuroimaging Cases in the Criminal Trial Process, 2009 STAN. TeCH. L. REv. 4, 7-8 (2009) [hereinafter Perlin, And I See Through Your Brain] (discussing need to expand Ake to provide funds for neuroimaging tests and expert witnesses).

Ake was supplemented recently in McWilliams v. Dunn,

S. Ct.

2017 WL 2621234

(2017), in which the Supreme court held - in a narrow 5-4 decision, per Justice Breyer-that the State had failed to meet its obligations under $A k e$ in a case in which neither the neuropsychologist who had examined defendant nor any other expert helped defense evaluate the report or capital murder defendant's extensive medical records and translate such data into legal strategy, and, when defense counsel asked for additional assistance at sentencing hearing, the trial judge rebuffed his requests.

209. In re K.G.F, 2001 MT 140, $\$ 33,306$ Mont. 1, 29 P.3d 485.

210. See PERLIN \& CuCOLO, supra note 80, at 91-96.

211. On the parallel issue of how counsel needs special skills to deal with conflicts in representation in civil commitment cases, see Michael L. Perlin \& Robert L. Sadoff, Ethical Issues in the Representation of Individuals in the Commitment Process, 45 L. \& LAW CONTEMP. PROBS. 161 (1982); Perlin \& Weinstein, "Said I, 'But You Have No Choice,", supra note 185.

212. See supra text accompanying note 196.

213. Specific knowledge about the diagnosis or tests relevant to the client is needed so that better cross-examination of the state's expert can be accomplished. PERLIN \& CuCOLO, supra note 80 , at 103. 


\section{ON THERAPEUTIC JURISPRUDENCE ${ }^{214}$}

Therapeutic jurisprudence (TJ) "asks us to look at law as it actually impacts people's lives"215 and focuses on the law's influence on emotional life and psychological well-being. ${ }^{216}$ The ultimate aim of therapeutic jurisprudence is to determine whether legal rules, procedures, and lawyer roles can or should be reshaped "to enhance their therapeutic potential while not subordinating due process principles." 117 There is an inherent tension in this inquiry, but David Wexler clearly identifies how it must be resolved: The law's use of "mental health information to improve therapeutic functioning [cannot] impinge upon justice concerns." $" 218$

One of the central principles of $\mathrm{TJ}$ is a commitment to dignity. ${ }^{219}$ Professor Amy Ronner describes the "three Vs" 220 as:

- voice $^{221}$ : litigants must have a sense of voice or a chance to tell their story to a decision maker;

- validation: the decision maker needs to take seriously the litigant's story; and

- voluntariness: in general, human beings prosper when they feel that they are making, or at least participating in, their own decisions. $^{222}$

214. This Part is generally adapted from Michael L. Perlin \& Alison J. Lynch, "All His Sexless Patients:" Persons with Mental Disabilities and the Competence to Have Sex, 89 WASH. L. Rev. 257, 277-79 (2014) and Michael L. Perlin \& Alison J. Lynch, "In the Wasteland of Your Mind: "Criminology, Scientific Discoveries and the Criminal Process, 4 VA. J. CRIM. L. 304, 34758 (2016). Further, it distills the work of one of the co-authors (MLP) over the past two decades, beginning with Michael L. Perlin, What Is Therapeutic Jurisprudence?, 10 N.Y.L SCH. J. HuM. RTS. 623 (1993).

215. Bruce J. Winick, Foreword: Therapeutic Jurisprudence Perspectives on Dealing with Victims of Crimes, 33 Nova L. REv. 535, 535 (2009).

216. See David B. Wexler, Practicing Therapeutic Jurisprudence: Psycholegal Soft Spots and Strategies, in Dennis P. STOLLE et AL., Practicing TheraPeutic JuRISPRUdence: LAW AS A HELPING PROFESSION 45 (2000).

217. See, e.g., Michael L. Perlin, "And My Best Friend, My Doctor/Won't Even Say What It Is I've Got": The Role and Significance of Counsel in Right to Refuse Treatment Cases, 42 SAN DIEGO L. REV. 735, 751 (2005).

218. David B. Wexler, Therapeutic Jurisprudence and Changing Concepts of Legal Scholarship, 11 BEHAV. SCI. \& L. 17, 21 (1993).

220. See Bruce J. Winick, Civil Commitment: A Therapeutic Jurisprudence Model 161 (2005).

220. See, e.g., Amy D. Ronner, The Learned-Helpless Lawyer: Clinical Legal Education and Therapeutic Jurisprudence as Antidotes to Bartleby Syndrome, 24 TOURO L. REV. 601, 627 (2008).

221. On the importance of "voice," see Ian Freckelton, Therapeutic Jurisprudence Misunderstood and Misrepresented: The Price and Risks of Influence, 30 T. JEFFERSON L. REV. 575,588 (2008).

222. Amy D. Ronner, Songs of Validation, Voice, and Voluntary Participation: Therapeutic Jurisprudence, Miranda and Juveniles, 71 U. CIN. L. REV. 89, 94-95 (2002). 
"The perception of receiving a fair hearing is therapeutic because it contributes to the individual's sense of dignity and conveys that he or she is being taken seriously." 223 In a recent article about dignity and the civil commitment process, Professors Jonathan Simon and Stephen Rosenbaum embrace therapeutic jurisprudence as a modality of analysis, and focus specifically on this issue of voice: "When procedures give people an opportunity to exercise voice, their words are given respect, decisions are explained to them their views taken into account, and they substantively feel less coercion."224 Certainly, the Supreme Court's recent focus on dignity and the perceptions of justice are, perhaps, its first implicit endorsement of important principles of therapeutic jurisprudence in a criminal procedure context. ${ }^{225}$

How can legal representation comply with TJ mandates and the basic dignity concepts and structures, in SVPA cases? In an earlier article, the co-authors concluded that substantive SVPA case law tells us that the variables that make SVPA litigation different-the need for lawyers to be able to understand, contextualize and effectively cross-examine experts on specific actuarial tests; recognition of when an expert witness is needed; and the overwhelming potential for bias (making the ideal of a fair trial even more difficult to accomplish)—demands a TJ approach to representation. A cursory examination of SVPA cases litigated on the right-to-counsel issue demonstrate beyond any doubt that the "voice" required in Professor Ronner's formulation of TJ is missing, and that we have no basis on which to make a reasoned conclusion as to whether "validity" is present. This is even more important since the notion of "voluntariness" is certainly absent. ${ }^{226}$

We believe that it is only through the use of $\mathrm{TJ}$ that we can best diminish the shaming and humiliating aspects of these processes. We know that nothing so clearly violates "the dignity of persons as treatment that demeans or humiliates them" as shaming. ${ }^{227}$ To be consistent with $\mathrm{TJ}$ principles we must, rather, focus on reintegrating sex offenders into

223. Michael L. Perlin, Keri K. Gould \& Deborah A. Dorfman, Therapeutic Jurisprudence and the Civil Rights of Institutionalized Mentally Disabled Persons: Hopeless Oxymoron or Path to Redemption?, 1 PSYCHOL. PUB. POL'Y \& L. 80, 114 (1995).

224. Jonathan Simon \& Stephen A. Rosenbaum, Dignifying Madness: Rethinking Commitment Law in an Age of Mass Incarceration, 70 U. MIAMI L. REV. 1, 51 (2015).

225. See Perlin \& Weinstein, supra note 31 , at $17 \mathrm{n} .87$; Michael L. Perlin \& Heather Ellis Cucolo, Mental Disability LaW: Civil and CRiminal § 13-2.4, at 13-131 (3d ed. 2016). Consider, in this context, Indiana v. Edwards, 554 U.S. 164, 176 (2008) (holding that "a right of self-representation at trial will not 'affirm the dignity' of a defendant who lacks the mental capacity to conduct his defense without the assistance of counsel," noting that "the spectacle that could well result from his self-representation at trial is at least as likely to prove humiliating as ennobling," discussed supra text accompanying notes 162-63).

226. Cucolo \& Perlin, "Far from the Turbulent Space," supra note 7, at 166.

227. Wright, supra note 133 , at 549. 
society and promoting sex offenders' self-respect and dignity while fostering family and community relationships. ${ }^{228}$

Consider here how $\mathrm{TJ}$-focused lawyers could initiate conversations with SVPA clients prior to the start of a hearing: ${ }^{229}$

Have you considered all the potential outcomes if you either acknowledge your guilt or adhere to denying guilt? ? $^{230}$

Are there witnesses that we could call to testify on your behalf that would give the judge a fuller picture of who you are? ? $^{231}$

Are there any organizations that you were active in before you were incarcerated-church, civic group? Is there someone from that group whom you'd like me to contact on your behalf?

Are there records or documents in the file of this case that you'd like to see so that you can tell if there are any inaccuracies? ? $^{232}$

Can I answer any questions or help you better understand any of the documents in your file?

Is there anything troubling you that you haven't told me about; do you want me to see if I can arrange for an outside expert to come to see you to talk to you about it? ? $^{233}$

If we lose and you remain institutionalized, are there arguments I should make so as to best insure your emotional well-being "while inside"? 234

228. Cucolo \& Perlin, Preventing Sex-Offender Recidivism, supra note 23, at 75.

229. For examples of conversations for clients raising the insanity defense or the incompetency to stand trial status, see Michael L. Perlin, "Too Stubborn To Ever Be Governed By Enforced Insanity": Some Therapeutic Jurisprudence Dilemmas in the Representation of Criminal Defendants in Incompetency and Insanity Cases, 33 INT'L J.L. \& PSYCHIATRY 475, 48081 (2010), and for criminal defendants prior to sentencing, Michael L. Perlin, "I Expected It to Happen/I Knew He'd Lost Control": The Impact of PTSD on Criminal Sentencing after the Promulgation of DSM-5, 2015 UTAH L. REv. 881, 924-25 (2015). For the significance of such dialogues in a therapeutic jurisprudence-based practice, see Michael L. Perlin, "Have You Seen Dignity?": The Story of the Development of Therapeutic Jurisprudence, U.N.Z. L. REv. (forthcoming 2017), available at https://papers.ssrn.com/sol3/papers.cfm?abstract_id=2932149 [hereinafter Perlin, Have You Seen Dignity?].

230. In many jurisdictions, incarcerated offenders who deny guilt cannot enter treatment programs. David A. Singleton, Kids, Cops, and Sex Offenders: Pushing the Limits of the InterestConvergence Thesis, 57 How. L.J. 353, 390-91 (2013).

231. Bringing in such witnesses to testify would also help to generate an appropriate and acceptable release plan.

232. In many jurisdictions, persons subject to SVPA proceedings are not given their case files, and often hear damning evidence for the first time at the trial itself. It is an open question whether the case of Pennsylvania v. Ritchie, 480 U.S. 39 (1987) (plurality opinion), in which the Supreme Court found no Confrontation Clause violation when the defendant in a child abuse case was denied access to the confidential file of a protective services agency, would apply to such a case.

233. This is not a forensic expert for the trial but a mental health practitioner who can provide counseling to the client.

234. PERLIN \& CUCOLO, supra note 80 , at $170-72$. 
A fair hearing - with dedicated, trained counsel-is therapeutic because it contributes to the individual's sense of dignity and conveys that he or she is being taken seriously."235

\section{How Should Counsel be Trained?}

In an insightful article, Professors Sarah Katz and Deeya Haldar suggest that lawyers incorporate trauma-informed practice in their skill set. ${ }^{236}$ Trauma-informed practice recognizes the impact of trauma on systems and individuals. ${ }^{237}$ Trauma-informed practice ensures that clients have access to trauma-focused interventions during all routine practice. ${ }^{238}$ These interventions incorporate an assessment of trauma and trauma symptoms and endeavor to treat the consequences of traumatic stress. ${ }^{239}$ Instead of asking, "What is wrong with you?" a trauma-informed practitioner asks, "What happened to you?"240 This approach has the potential to reform legal representation by emphasizing the benefits of therapeutically-informed interactions. Professors Katz and Halder suggest, and we fully agree that "law schools can and should teach trauma-informed lawyering, particularly in the law clinic setting."241 They conclude this would go "a long way in helping students adjust their practice skills to competently and zealously represent clients who have experienced trauma." 242 But there is more than this. Just as the Montana Supreme Court "got" the fact that counsel was likely to be inadequate in involuntary civil commitment cases ${ }^{243}$ so must courts presiding over SVPA cases "get" the fact that counsel is similarly likely to be inadequate here.

To make it more likely that lawyers actually do provide adequate counsel, we thus offer these as baseline elements of a training program.

235. Perlin \& Weinstein, supra note 31 , at 49.

236. Sarah Katz \& Deeya Haldar, The Pedagogy of Trauma Informed Lawyering, 22 CliniCAL L. Rev. 359, 363 (2016).

237. Id. at 369 .

238. Id. at 363 .

239. Id.

240. Id. The authors pointedly note: "The trauma experiences of clients have a direct relationship to how they relate to their attorneys and the courts, because trauma has a distinct physiological effect on the brain, which in turn affects behavior in the short-term and long-term." Id. at 366 .

241. Id. at 372 .

242. Id. at 393. On the significance of the phraseology of such questions, see Kristin Henning, Race, Paternalism, and the Right to Counsel, 54 AM. CRIM. L. REv. 649, 690-91 (2017).

243. See In re Mental Health of K.G.F., 2001 MT 140, If 34-35 306 Mont. 1, 29 P.3d 485; see also Perlin \& Cucolo, "Far from the Turbulent Space," supra note 7, at 158. 


\section{A. The "Back Story"}

Lawyers must be trained in the "back story" that led to the creation of actuarial instruments, and, must understand that, notwithstanding the fact that such instruments do lead to far more accurate results than do unstructured clinical interviews, such instruments often assume facts-notin-evidence as to the individuals being assessed. For example:

(a) Individuals are penalized for never having been married. ${ }^{244}$ This scoring has a disparate impact on those who are intellectually disabled who, for multiple reasons, marry at a far lower rate than do those not so disabled.

(b) Tests are normed on certain groups of individuals (e.g., Canadian, Caucasian males) ${ }^{245}$ There is a serious question as to the reliability and validity of the studies that led to this norming population if the individual in question is, say, an African-American.

This training will optimally lead lawyers to contest the validity of the actuarial instruments on voir dire, and at the least, raise the inference with the judge that the resulting numbers are not "magic" or a "gold standard." $" 246$

\section{B. Sanist and Pretextual Myths}

Lawyers must be trained in the sanist and pretextual myths ${ }^{247}$ that lead fact finders to make gross misassumptions about persons who are subject to the SVPA process (e.g., that "no treatment works"; that "they all recidivate"; that the stranger-in-the-parking-lot scenario is the most common fact pattern), in the ways that heuristic reasoning dominates fact-finders' thought process (including, not limited to, the vividness heuristic), ${ }^{248}$ and in the ways that fact-finders' false "ordinary common sense" leads them to make fatally erroneous assumptions as a result of pre-reflective thinking, and observations based disproportionately on

244. Shoba Sreenivasan et al., Alice In Actuarial-Land: Through the Looking Glass of Changing Static-99 Norms, 38 J. AM. ACAD. PSYCHIATRY \& PSY. L. 400, 403 (2010), http://jaapl.org/content/38/3/400.

245. Id. at 402 .

246. See, e.g., Robert J. B. Lehmann et al., Applying Crime Scene Analysis to the Prediction of Sexual Recidivism in Stranger Rapes, 37 L. \& HUM. BEHAv. 241, 243, 250 (2013) ("the Static$99 .$. is currently the gold-standard in sexual recidivism prediction.").

247. On sanism and pretextuality, see supra text accompanying notes 173-81.

248. The vividness heuristic is the cognitive-simplifying device through which a "single vivid, memorable case overwhelms mountains of abstract, colorless data upon which rational choices should be made." Michael L. Perlin, "The Borderline Which Separated You from Me": The Insanity Defense, the Authoritarian Spirit, the Fear of Faking, and the Culture of Punishment, 82 IOWA L. REv. 1375, 1417 (1997). 
visual cues and clues ("he looks creepy"). ${ }^{249}$ As one of the co-authors (MLP) has recently written, "attorneys representing [persons with mental disabilities] need not only effective advocacy skills training, but also training in the realm of $\mathrm{TJ}$ to directly rid them of conscious or unconscious sanist biases." 250

\section{Developing Dialogues}

Lawyers need to be trained in the development of dialogues with their clients so as to best maximize the therapeutic jurisprudence outcomes of the SVPA process. ${ }^{251}$ The use of TJ in this context will "help to create a feeling of connectedness" between the lawyer and her client, ${ }^{252}$ and will make it far more likely that clients will be given the sense of dignity, voice, and validation that $\mathrm{TJ}$ demands.

\section{A Second Witness?}

Lawyers must be trained so that they understand when a second expert witness is needed - not solely the one who examines the client, but a second to offer empirical research to rebut the assumptions regularly made by the fact finder. ${ }^{253}$ In this specific context, lawyers must be trained so that they can raise arguments urging the expansion of the Supreme Court's decision in Ake v. Oklahoma, so as to mandate expert availability in this cohort of these cases as well. ${ }^{254}$

249. On how jurors look for such clues and cues in death penalty cases, see Michael L. Perlin, "Life Is in Mirrors, Death Disappears": Giving Life to Atkins, 33 N. MEx. L. Rev. 315, 333-34 (2003).

250. Michael L. Perlin \& Alison J. Lynch, "Mr. Bad Example": Why Lawyers Need to Embrace Therapeutic Jurisprudence to Root out Sanism in the Representation of Persons with Mental Disabilities, 16 WYO. L. REv. 299, 311 (2016).

251. See supra text accompanying notes 231-36. See generally Perlin, Hove you Seen Dignity?, supra note 229 , manuscript at $48-50$.

252. On how this applies to the sense of connectedness that $\mathrm{TJ}$ can bring about to law students, see Michael L. Perlin \& Alison J. Lynch, How Teaching about Therapeutic Jurisprudence Can Be a Tool of Social Justice, and Lead Law Students to Personally and Socially Rewarding Careers: Sexuality and Disability as a Case Example, 16 NEv. L.J. 209, 222 (2015).

253. Cucolo, \& Perlin, "Far from the Turbulent Space," supra note 7, at 158-64.

254. See, e.g., Perlin, "And I See Through Your Brain," supra note 208, at 7-8 (arguing that the rule of $A k e$ needs to be expanded to provide indigent defendants access to funds for neuroimaging tests and expert witnesses qualified to testify in cases involving such testimony), see also McWilliams v. Dunn discussed supra note 208; see also Michael L. Perlin, "Your Corrupt Ways Had Finally Made You Blind": Prosecutorial Misconduct and the Use of "Ethnic Adjustments" in Death Penalty Cases of Defendants with Intellectual Disabilities, 65 AM. U. L. REV. 1437, 1459 n.115 (2016) (arguing that the rule of $A$ ke needs to be expanded so as to provide such defendants with funds for expert witnesses who could rebut testimony that "ethnic adjustments" are permissible in death penalty cases); see generally Robert $M$. Sanger, $I Q$, Intelligence Tests, "Ethnic Adjustments," 65 AM. U. L. REv. 87 (2015). 


\section{E. Trauma-Informed Training}

Lawyers need to be trained to understand and incorporate traumainformed lawyering, ${ }^{255}$ as well as the basic language and concepts of mental health law (to understand the possible effects of a mental disability or personality disorder on the client, the significance of diagnoses, and the success/failure rates of common treatment methods with this population). ${ }^{256}$

In addition, lawyers require a full spectrum of knowledge regarding harm and resulting trauma for both the victim and the offender. For defense attorneys especially, this is relevant to fully appreciate the connection between an offender's own victimization - if it exists-and the crime that was committed. In a controversial book, ${ }^{257}$ The Trauma Myth: The Truth About the Sexual Abuse of Children-and Its Aftermath, Dr. Susan Clancy asserts that many professionals do not really understand how, why, and when child sexual abuse is harmful, and that imputing trauma when it is not present might actually introduce secondary harm. ${ }^{258}$ Making judgments about the degree of harm suffered by a victim and/or justifying criminal behavior because of previous victimization can be detrimental to client relations and subsequently the ability to effectively represent a case. ${ }^{259}$

We believe that lawyers assigned to represent individuals at SVPA hearings must undergo rigorous and ongoing training so as to provide authentically effective counsel, effectiveness that, as we noted before, "cannot be presumed in a proceeding that routinely accepts - and even requires - an unreasonably low standard of legal assistance and generally disdains zealous, adversarial confrontation."260

\section{CONCLUSION}

Some twenty years ago, writing about civil commitment law, right to treatment law and right to refuse treatment law, one of the co-authors (MLP), writing with others, said, "We believe that therapeutic jurisprudence analyses may be a strategy to redeem civil rights litigation in this area and to reinvigorate this body of mental disability law." ${ }^{261} \mathrm{~A}$

255. See supra text accompanying notes $236-42$.

256. See supra text accompanying notes 191-99.

257. Abigail Zuger, Abusing Not Only Children, But Also Science, N.Y. Times (Jan. 25, 2010), http://www.nytimes.com/2010/01/26/health/26zuger.html.

258. See generally Susan Clancy, The Trauma Myth: The Truth about the Sexual ABUSE OF CHILDREN-AND ITS AFTERMATH (2009).

259. Id. at 119 .

260. In re K.G.F., 29 P.3d 485, 492 (quoting Perlin, supra note 18, at 53-54).

261. Perlin, Gould \& Dorfman, supra note 223, at 84. 
few years later, this thought was expanded to argue that $\mathrm{TJ}$ "carries with it the potential to offer redemption for all mental disability law,"262 and then later, "to redeem the law for [all] persons who have been marginalized." 263

There is no group more marginalized than the persons about whom we write here, and this marginalization consistently causes shame, humiliation and lack of dignity for these individuals, and may in turn "diminish their investment in mainstream social values and increase their resentment toward society." 264 Our hope is that this Article inspires both lawyers and policy makers to take seriously the ways that shame and humiliation have contaminated the SVPA process and the ways that we have failed miserably at providing effective counsel for those subject to that process.

262. PERLIN, supra note 4, at 301.

263. Michael L. Perlin \& John Douard, Equality, I Spoke That Word/As if a Wedding Vow: Mental Disability Law and How We Treat Marginalized Persons, 53 N.Y. L. REv. 9, 14 (200809).

264. Jill S. Levenson et al., Megan's Law and its Impact on Community Re-Entry for Sex Offenders, 25 BEHAV. SCI. \& L. 587, 598 (2007). 